\title{
Design and validation of Virtual Reality software package with real images for treatment of attention deficit disorder symptoms
}

\author{
Fattaneh Khojastebakht $^{1}$, Javad Rasti ${ }^{2 *}$ iD , Mahgol Tavakoli ${ }^{3}$, Nasibeh Sarrami Foroushani ${ }^{4}$
}

\begin{abstract}
1. MSc of Biomedical Engineering, Department of Biomedical Engineering, Faculty of Engineering, University of Isfahan, Isfahan, Iran
2. Assistant Professor of Biomedical Engineering, Department of Biomedical Engineering, Faculty of Engineering, University of Isfahan, Isfahan, Iran

3. Assistant Professor of Psychology, Department of Psychology, Faculty of Education and Psychology, University of Isfahan, Isfahan, Iran

4. PhD Student of Psychology, Department of Psychology, Humanistic and Basic Science Faculty, Yazd Science and Art University, Yazd, Iran
\end{abstract}

Recieved: 11 Mar. 2019

Revised: 5 Apr. 2020

Accepted: 21 Apr. 2020

Keywords

Virtual reality

Attention deficit disorder (ADD)

Virtual therapy

Corresponding author

Javad Rasti, Assistant Professor of Biomedical Engineering, Department of Biomedical Engineering, Faculty of Engineering, University of Isfahan, Isfahan, Iran

Email: Rasti@eng.ui.ac.ir

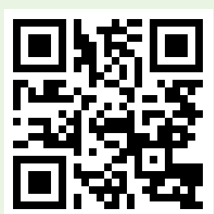

\section{Abstract}

Introduction: The inability to concentrate on a specific topic in the presence of distracting factors is of evident symptoms of Attention Deficit Disorder (ADD). Controlled simulation of such factors through immersion in real environments by Virtual Reality (VR) technology can be effective to improve attention. The study aims to design and validate a VR-based software package to decrease the effect of distraction factors and improve ADD symptoms.

Methods: The VR-based software package comprises 18 short panoramic footages with pre-determined scenarios, each of which includes the main topic and some irrelevant distracting factors. The intervention procedure includes watching two footages per session and answering the related questions. For content validation, five attention psychotherapists and five VR experts were selected on purpose, and after applying their revisory comments, the results of the validation questionnaires were analyzed to obtain the Cohen's Kappa coefficient. For introductory intervention, the population comprised all female students with ADD in grade six of the elementary school in 2017-18 academic years in Isfahan, Iran. A limited sample of 14 people was selected based on inclusion criteria and randomly assigned to equal experimental and control groups. The intervention was carried out for the experimental group in nine sessions, while the control group was on the waiting list. All subjects' parents completed the SNAP-IV questionnaires before and after the intervention period, and the results were analyzed the using non-parametric Mann-Whitney U test in SPSS-23.

Results: Cohen's Kappa coefficient of 0.83 shows acceptable content validity. The Mann-Whitney U test indicated the effectiveness of VR-based software package on improving attention in students with ADD $(\mathrm{F}=-3.232, \mathrm{P}=0.001)$

Conclusion: Simulating real distracting factors in an immersive VR platform can lead to an improvement in attention and reduce ADD symptoms. Moreover, customizing the virtual environment based on the subject's demands can provide an ideal therapy plan.

Citation: Khojastebakht F, Rasti J, Tavakoli M, Sarrami Foroushani N. Design and validation of Virtual Reality software package with Real images for treatment of attention deficit disorder symptoms. Advances in Cognitive Sciences. 2020;22(3):79-94. 


\title{
طراحى و روايعسنجى بسته نرمافزارى مبتنى بر واقعيت مجازى با تصاوير حقيقى جهت بهبود نشانكان نقص توجه
}

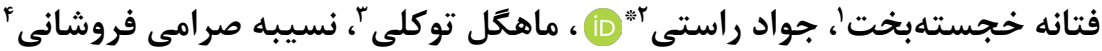

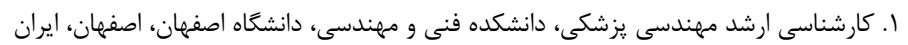

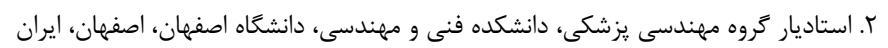

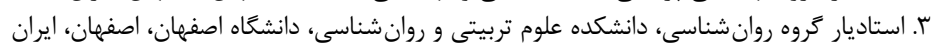

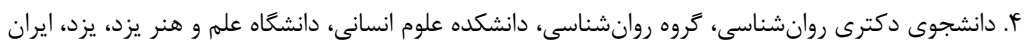

\begin{abstract}
ars
مقدمه: عدم تمركز با وجود عوامل مزاحم يكى از نشانگان نقص توجه است و شبيهسازى آنها در محيط واقعيت مجازى

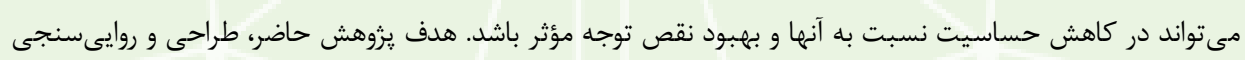
بسته نرمافزارى مبتنى بر واقعيت مجازى براى كاهش اثر عوامل حواسيرتى و بهبود نشانكان نقص توجه بود.

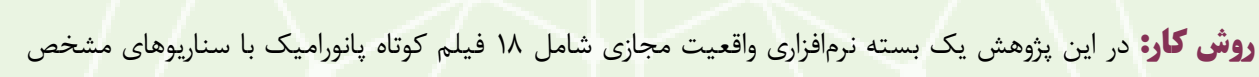
تدوين شد. براى سنجش اعتبار محتوايى از بين متخصصان نقص توجه و واقعيت مجازى، •ا نفر به صورت هدفمند انتخاب شده و نرمافزار در اختيار آنها قرار كرفت و ضريب توافق كايا تحليل شد. براى اجراى مقدماتى، از بين دانشآموزان دختر مبتلا به نقص توجه كلاس ششم ابتدايى اصفهان، يك نمونه If نفرى به شيوه در دسترس انتخاب و به طور تصادفى در دو گروه مساوى آزمايش و كنترل گمارده شدند. مداخله به مدت 9 هفته و \1 جلسه براى گروه آزمايش انجام شد و َروه كنترل در ليست انتظار قرار گرفت. يرسشنامه SNAP-IV توسط والدين آزمودنىها در دو مرحله يِيشآزمون و يسآزمون تكميل و نتايج با استفاده از آزمون منويتنى در نرمافزار SPSS-23 تحليل شد. يافتهها: ضريب كاياى سی| • نشاندهنده اعتبار محتوايى روش مزبور است. نتايج آزمون منويتنى بيانكر تأثير نرمافزار

$$
\text { فوق بر بهبود نشانعان نقص توجه دانشآموزان بود ( }
$$

نتيجه كيرى: فناورى واقعيت مجازى با شبيهسازى عوامل مؤثر در بروز حواسيرتى در يك بستر مجازى و نيز با قابليت شخصىسازى محيط بر اساس نيازهاى بيمار مى تواند در بهبود نشانكان نقص توجه در كودكان موثر باشد.
\end{abstract}

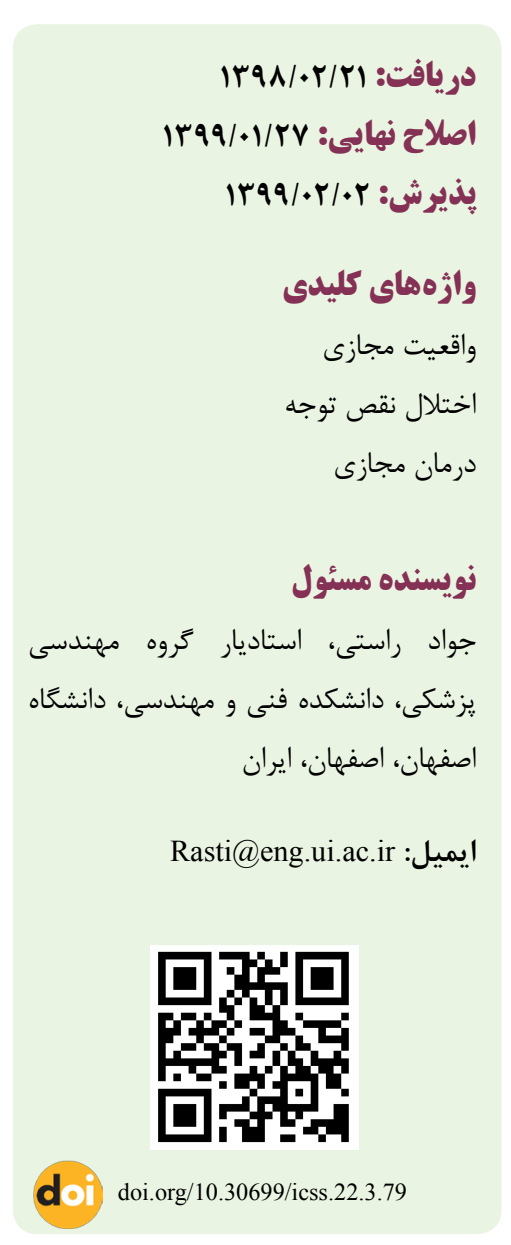

هouto

تمركز روى محركهاى غيرمرتبط خوددارى كند ( (، ؟). به بيان ديخر،

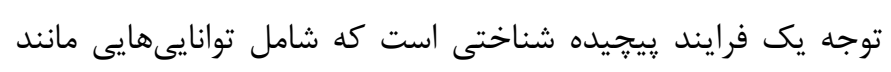
تمركز بر هدف، جابجايى تمركز از هدفى به هدف ديخر، نغاه داشتن تمركز روى هدف مشخص، گُش به زنگ بودن در زمان طولانى و شناخت ويزگى هاى محركهاى جانبى است (r). در يكى از مدلهاى
توجه يكى از محورهاى اصلى روان شناسى شناختى است كه در ساختار

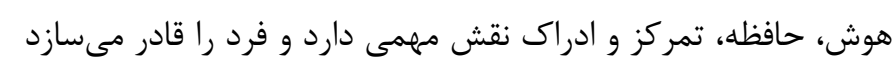
تا ورود محركهاى مختلف را به صحنه هوشيارى ذهن كنترل كند، آنها را سريع، صحيح و ييوسته مورد بررسى قرار دهد و از ميان آنها، محتل

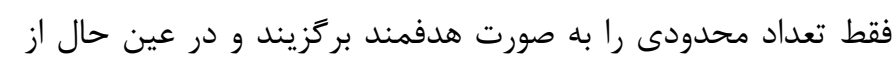


محر كها مىتوانند فراخناى توجه، كنترل برانگيختگى، خلاقيت تحصيلى و روابط اجتماعى را در كودكان مبتلا به نقص توجه بهبود بخشند، با باليا

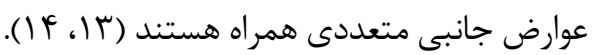

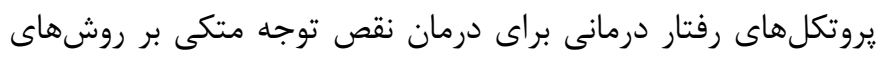

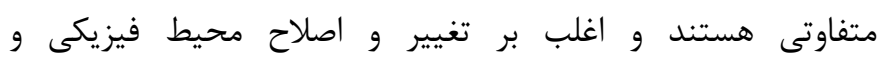

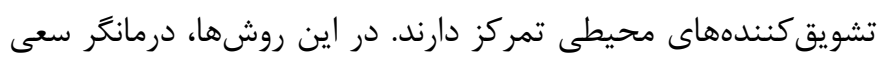

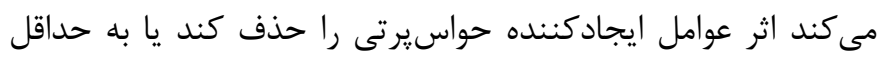
ممكن برساند و از اين طريق توجه آزمودنى بر تكليف را بيشتر كند (ه (). بازى درمانى در قالب فردى يا گروهى، روش رفتارى رايج ديكرى براى إى إن

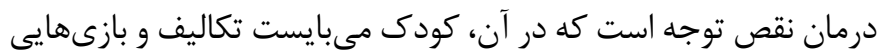
را انجام دهد و در حين بازى سعى در حفظ توجه بر تكليف و به پايان رساندن بازى داشته باشد (ع). تجربه نشان داده است اين بازى دها اغلب دائ

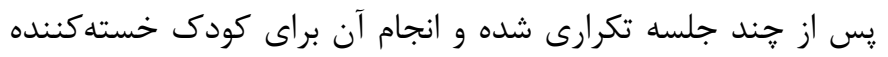

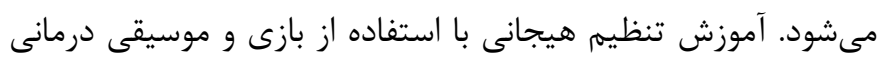

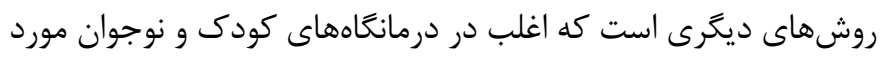

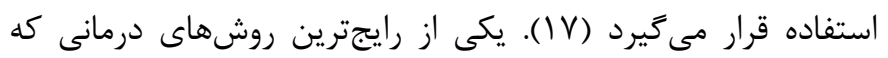
در حوزه اختلالات رفتارى كودكان داراى كاربردهاى وسيعى است،

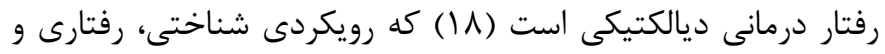
حمايتى تركيب شده با آموزههاى فلسفه شرق است. در اين رويكرد كه در ابتدا براى درمان اختلال شخصيت مرزى ابداع شد، بر بذيرش

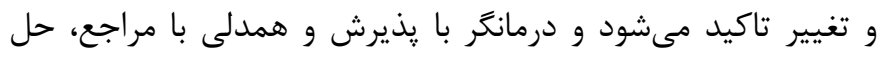

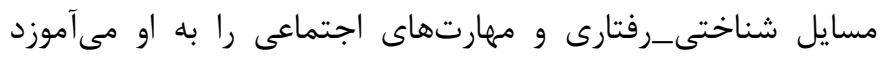

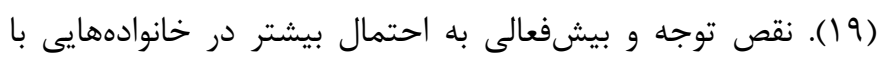

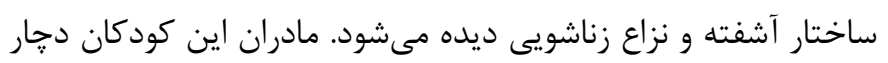

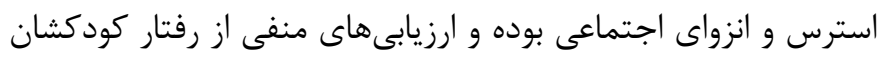

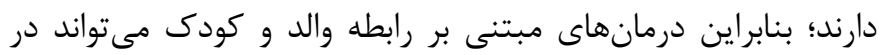
شيوههاى فرزنديرورى و در نتيجه بهبود نشانهاى اين اختلال مثمرثمر داني باشد (·r). يكى از روشهاى مبتنى بر اصلاح روابط خانوادگى، اصلاح تعامل والد_كودى مىباشد كه با تمركز بر آموزش والدين در طول

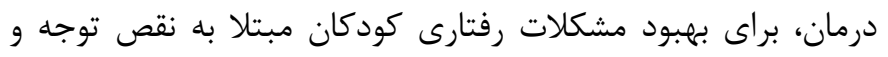

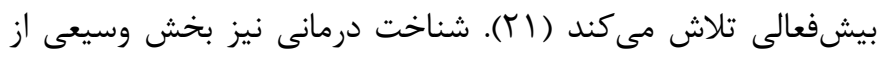

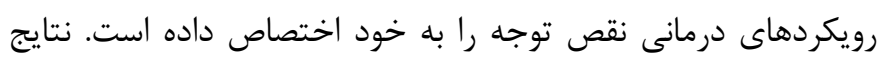

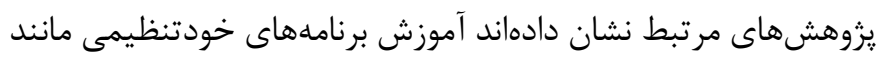

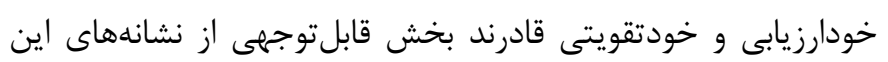
اختلال را بهبود بخشند (rT). لازم به ذكر است به دليل تنوع مشكلات مبتلايان به نقص توجه، اغلب متخصصان راهبردهاى درمانى متعددى را به صورت تركيبى اتخاذ مى كنند.
بالينى سلسلهمراتبى توجه، انواع توجه به صورت توجه متمركز، توجه انتخابى، توجه يايدار، توجه تناوبى و توجه تقسيمشده ردهبندى مى إشود.

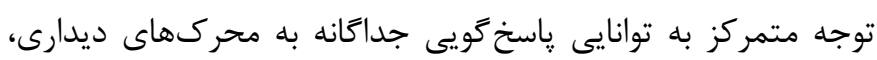

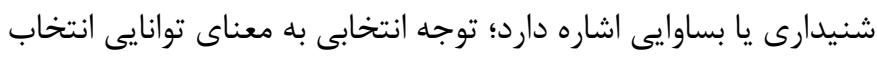

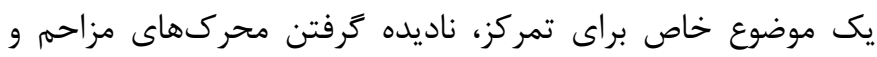

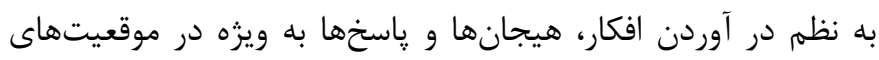

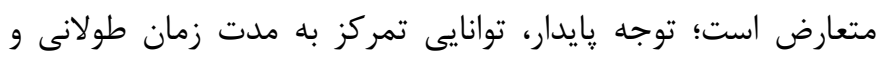
توجه تقسيمشده توانايى توجه بر بيش از يك مورد به صورت همزمان

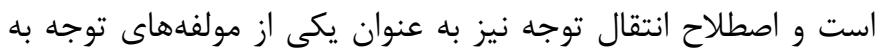
توانيى جابجا شدن توجه بين موضوعات متفاوت اشاره دارد (\&). توجه به عنوان بستر ساير فعاليتهاى شناختى قلمداد مىشود و اختلال در آن، هسته اصلى بسيارى از اختلالات روانشناختى است. افراد دهار

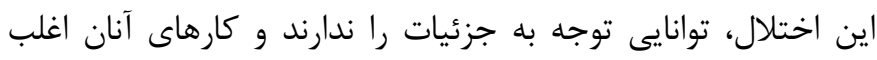

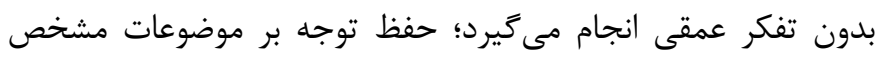

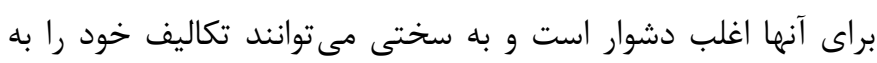

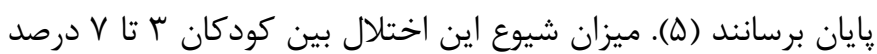
كزارش شده است (9) و عدم درمان مناسب آن مىتواند به اختلالات جدىتر شناختى و رفتارى در بزرَسالى منجر شود. بر اساس نظريه Barkley توانايى كنترل و بازدارى در كودكان و بزر كسالان مبتلا به ديه اختلال نقصتوجه/بيشفعالى دجار اشكال جدى مىشود (V) كه به نوبه

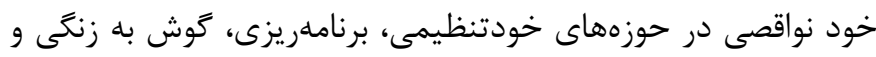
واكنش به محركها ايجاد مى كند (^). همجنين اين اختلال مشكلات

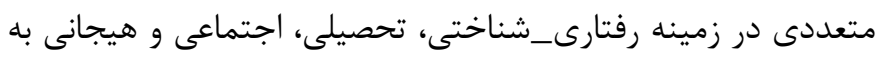

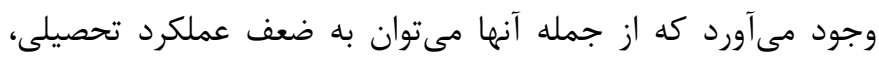

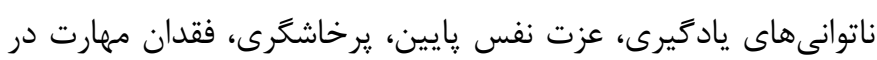

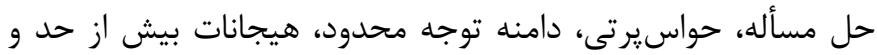
ارتباط نامناسب با همسالان اشاره كرد (9). يكى از عواملى كه مىتواند در ايجاد اختلال نقص توجه نقش داشته باشد، ضعف در كاركردهاى اجرايى است كه با توانايىهاى ذهنى از جمله

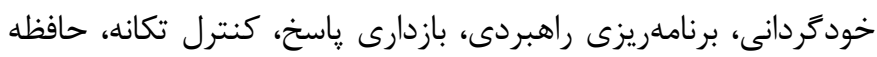

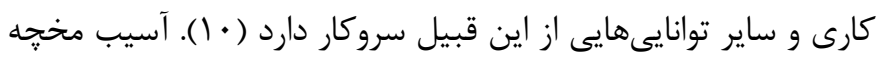

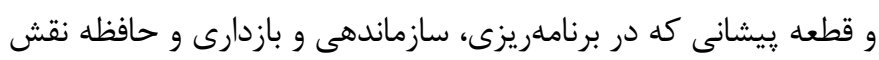
دارد نيز در سببشناسى نقص توجه كزارش شدهاند (1) (1). همجنين

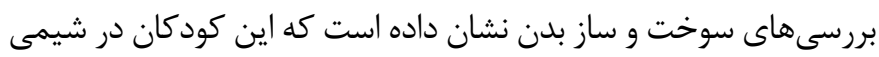
عصبى مغز تفاوتهاى متمايزى را با ساير كودكان نشان مىدهند (r) (I). درمان مرسوم اين اختلال، تجويز داروهاى محرك سيستم اعصاب مركزى

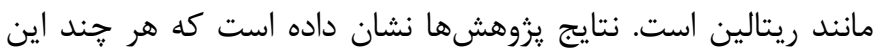


و كنترل تفاوت معنادارى وجود دارد. به بيان ديكر آموزش نوروفيدبك باعث بهبود توجه مستمر در افراد شده است. در يزوهشى ديخر،

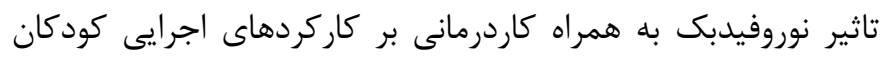

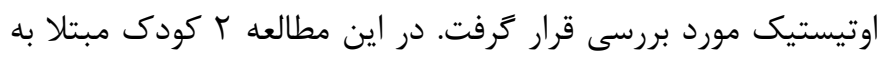

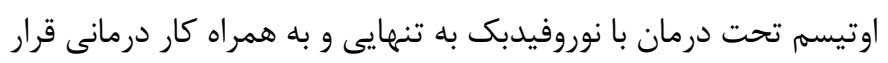

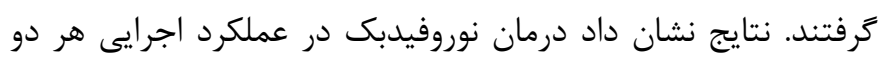

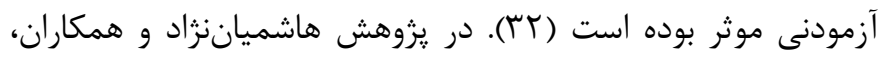

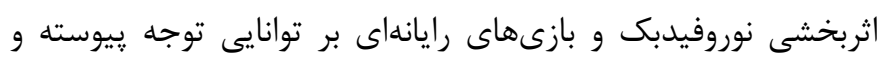

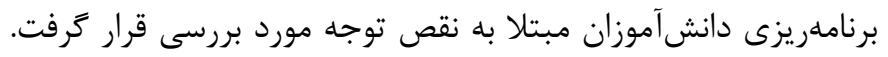

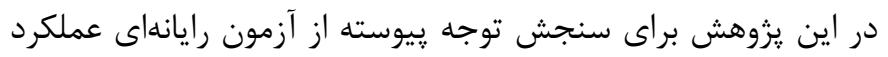

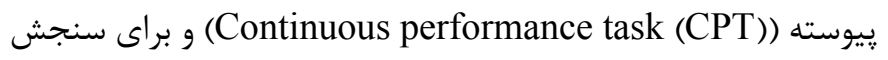
توانايى برنامهريزى از آزمون برج لندن استفاده و جلسات نوروفيدبك

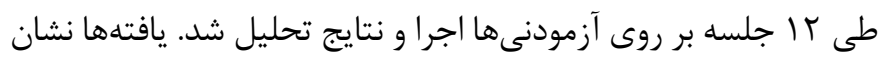

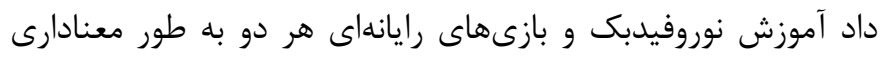

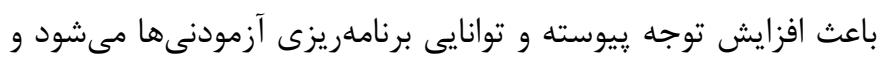
بين اين دو روش تفاوت معنادارى وجود ندارد (بسا). يكى از فناورىهاى نوين حوزه سركرمى، واقعيت مجازى (Reality) (Virtual است كه با شبيهسازى يك موقعيت واقعى در بستر مجازى، لوارين

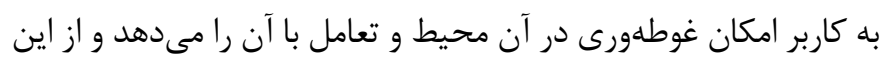

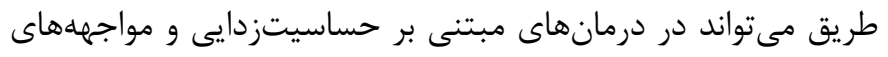

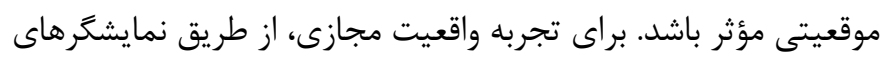

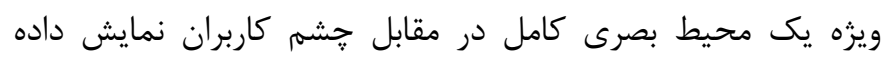

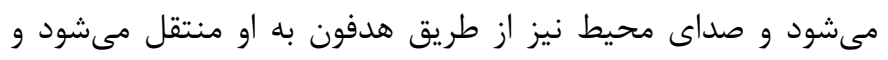

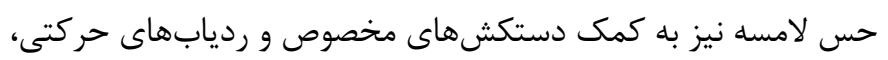

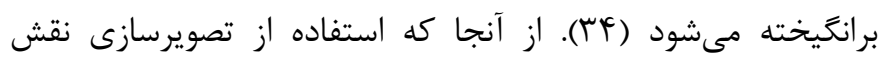

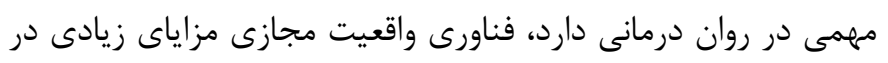

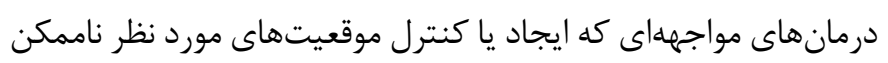

$$
\text { يا سخت و هزينهبر است، ايجاد مى كند. }
$$

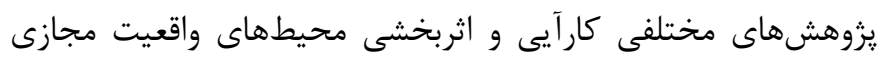

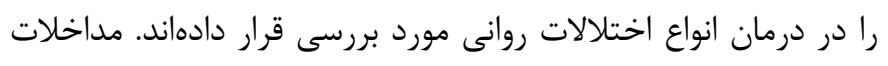

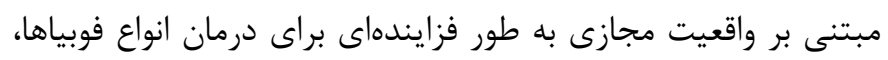

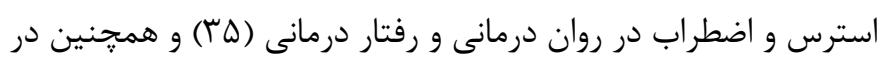

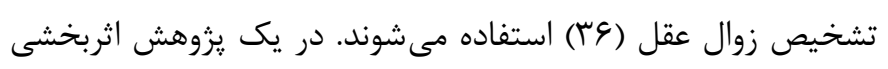

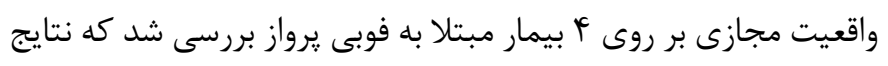

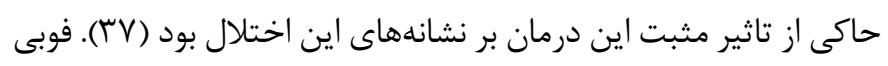

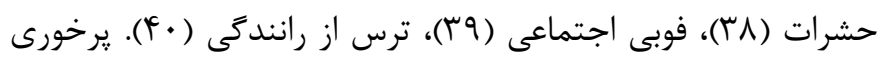

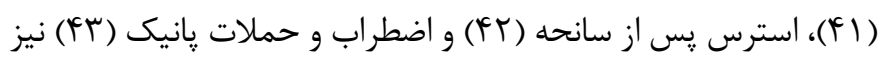

در كنار شيوههاى مرسوم و سنتى براى درمان نقص توجه، بهرهيرى

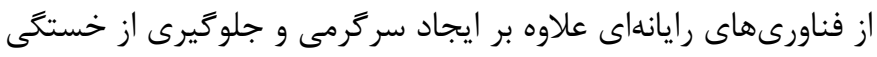

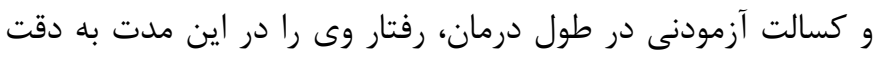

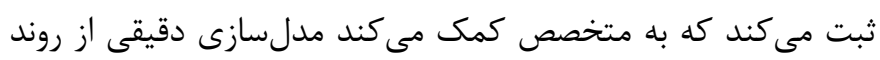

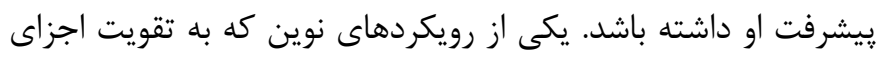

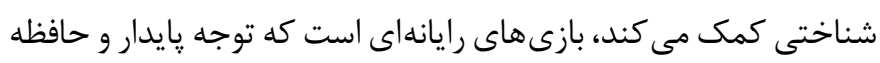

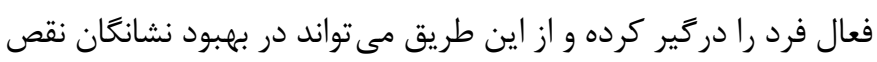

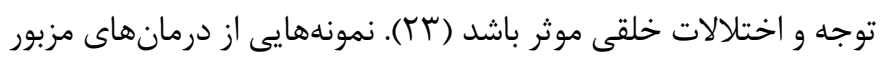

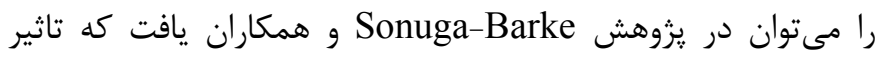

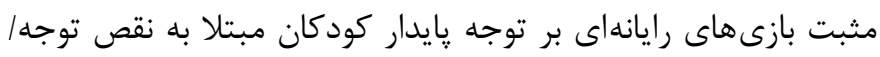

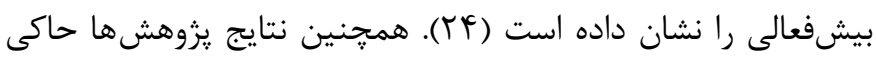

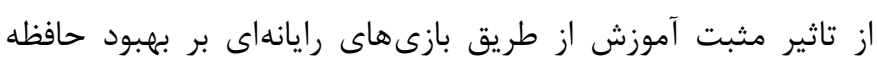

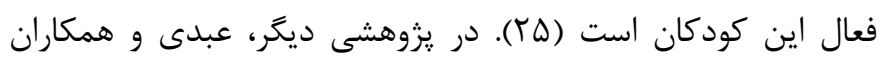

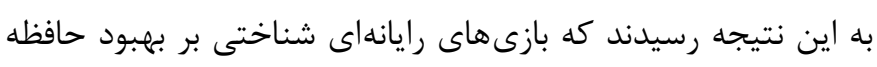

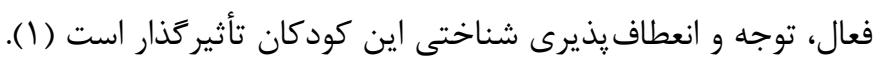

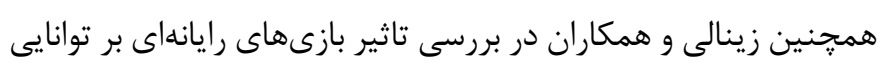

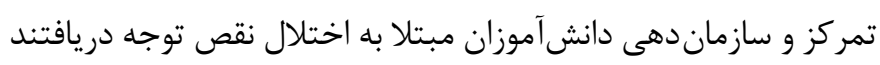

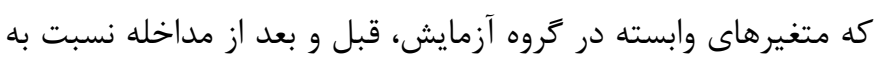
كروه كنترل تفاوت معنادارى داشته است (צای (؟).

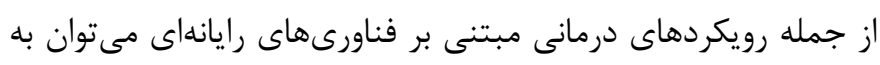

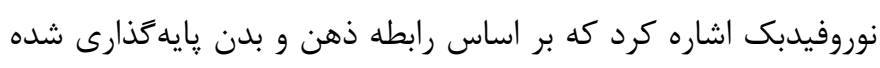

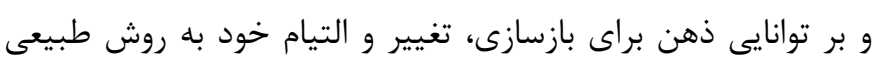

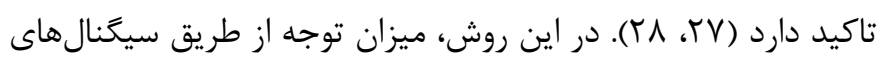

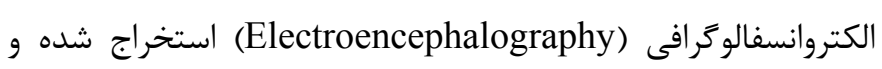
براى كنترل رفتار يك عامل رايانهاى در محيط يك نرمافزار يا بازى

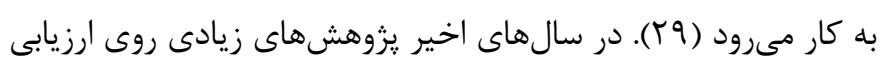

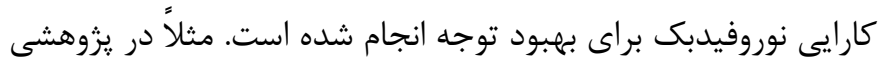

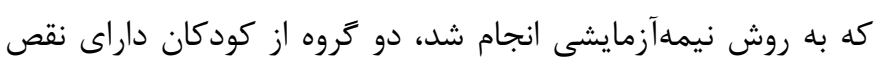

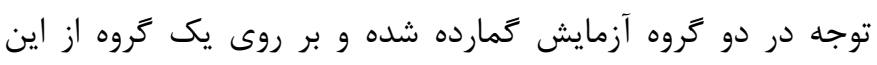

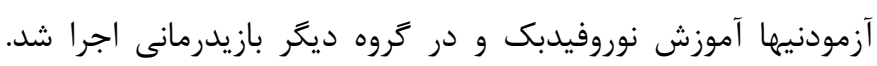
نتايج اين يزوهش نشان داد كروهى كه تحت آموزش نوروفيدبك قرار

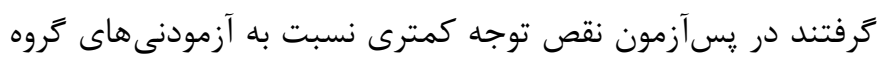

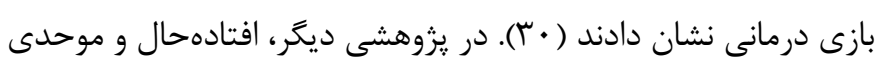

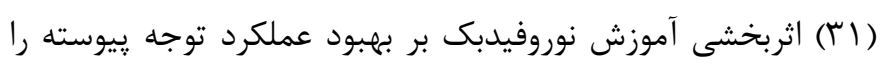

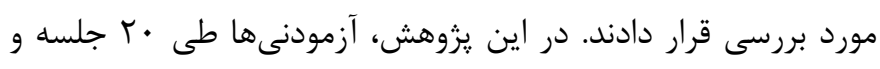

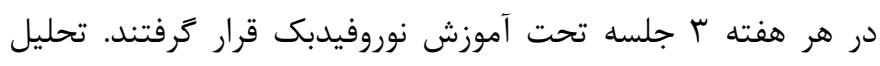

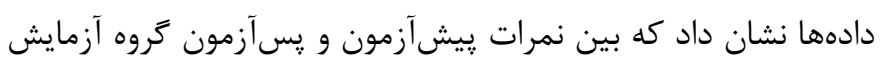


مبتلا به نقص توجه و بيشفعالى مورد بررسى قرار گرفت. نتايج نشان داد محيط واقعيت مجازى به دليل ايجاد حس غوطهورى، جذابيت و

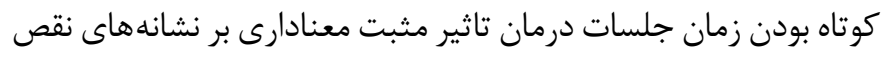

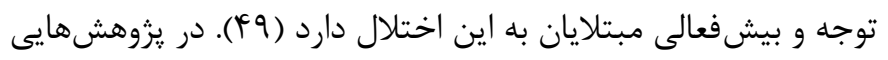

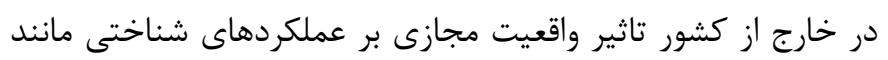

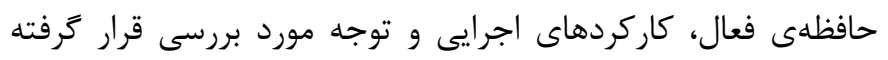

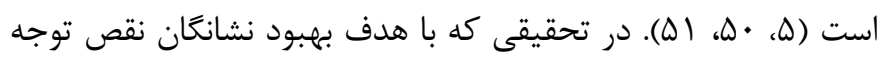

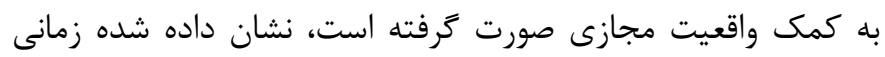

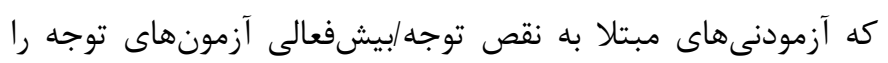
در محيط واقعيت مجازى انجام مىدهند، نمرات بهترى در مقايسه

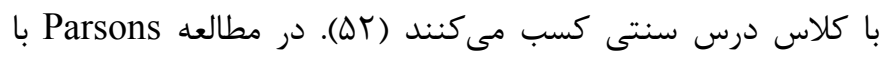

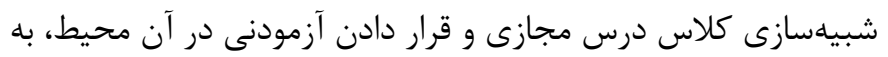

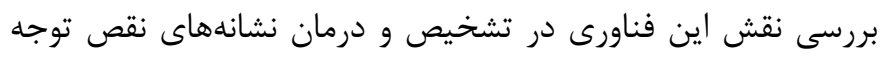

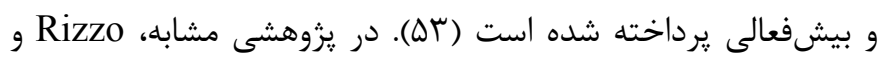

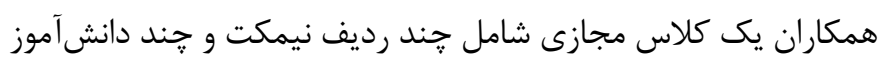

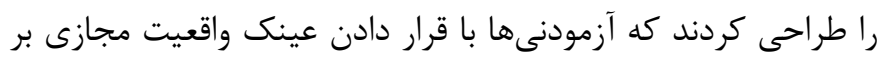

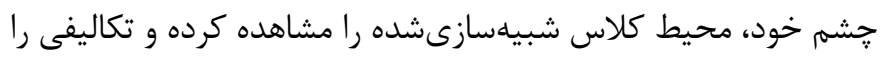
انجام مىدادند. در حين انجام تكاليف، محركهاى ديدارى و شنيدارى

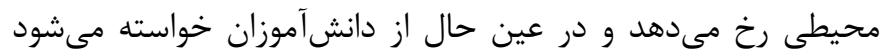

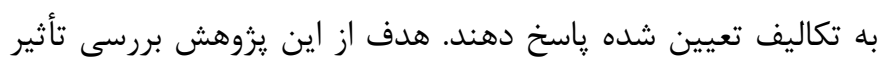

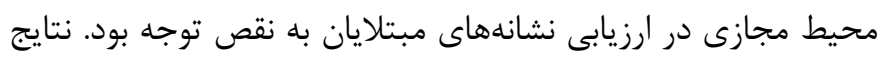

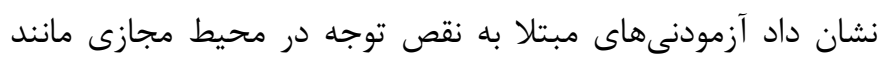

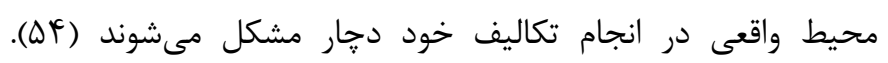

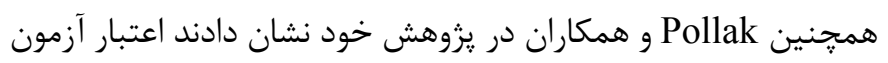
عملكرد در كلاس مجازى نسبت به كلاس درس واقعى بيشتر است

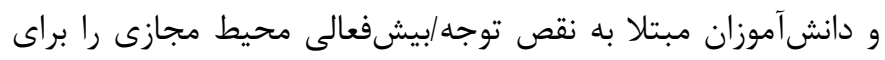
يادگيرى ترجيح مىدهند (DQ). Ehlis در مطالعه خود به بررسى اثربخشى نوروفيدبك در كلاس درس مجازى يرداخته است. در اين

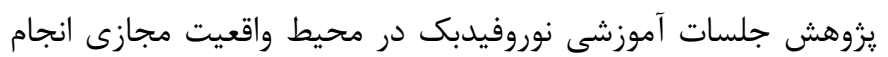

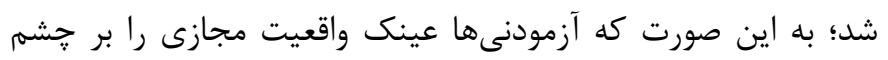

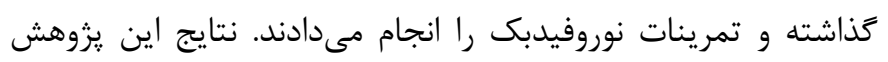

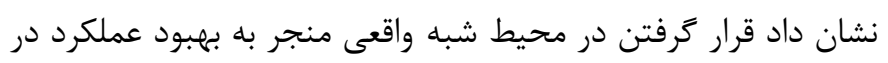

تمرينات نوروفيدبك مىشود (ه)). يزوهشهاى مزبور همغى از واقعيت مجازى شبيهسازى شده استفاده

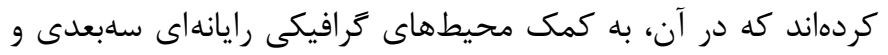
كنترل كنندههاى بيشرفته، غوطهورى و تعامل با محيط ميسر مىشود.

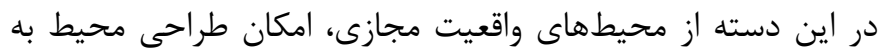

از ديخر اختلالات روانشناختى رايج هستند كه به تازگى مورد توجه

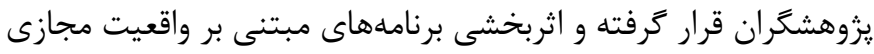

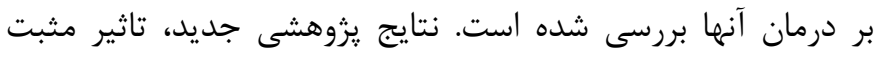

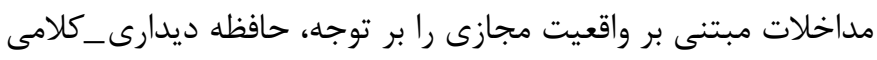

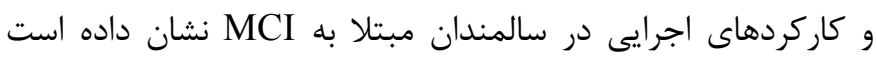

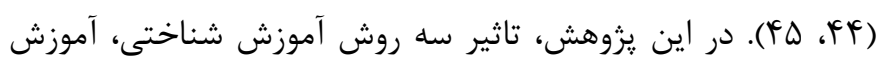

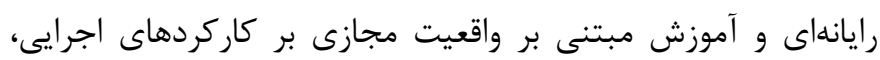

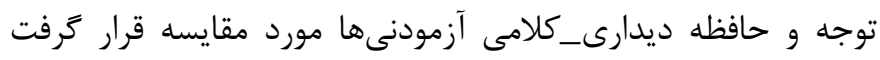
كه نتايج حاكى از اثربخشى معنادار واقعيت مجازى بر بهبود فراخناى دارئ

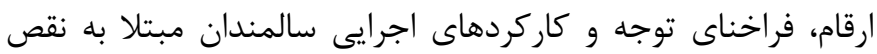

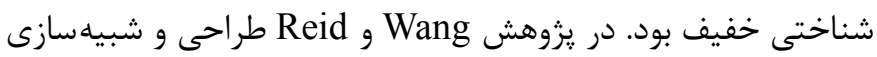
كلاس درس واقعى در محيط واقعيت مجازى و بررسى اثربخشى اين

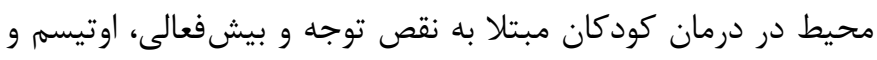

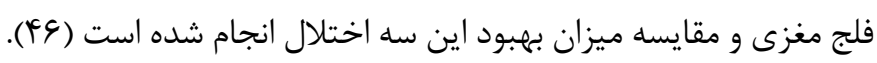

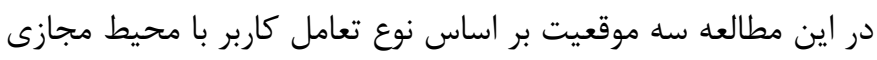

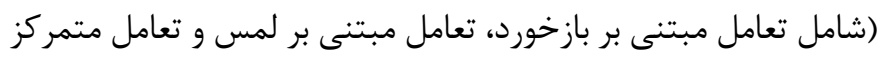

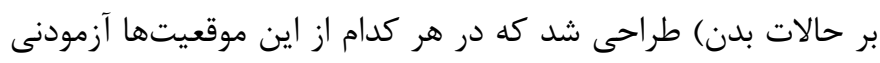
مىبايست به نحو خاصى با محيط تعامل كند. براى مثال در تعامل

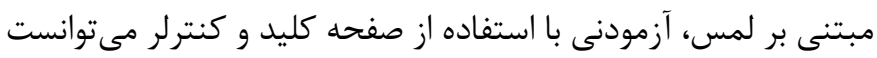

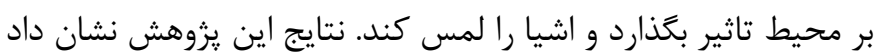

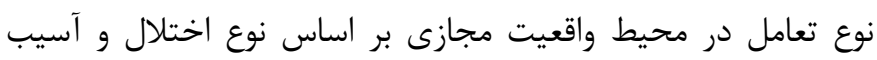
متفاوت است و محيطهاى مختلف تاثير متفاوتى بر اختلالات گوناكون

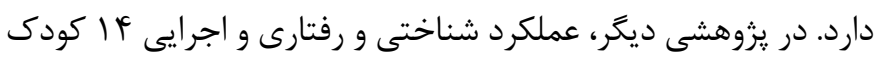

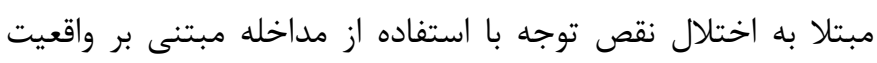

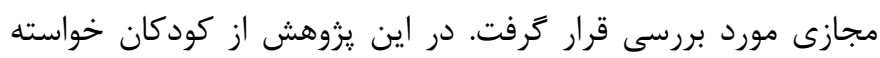

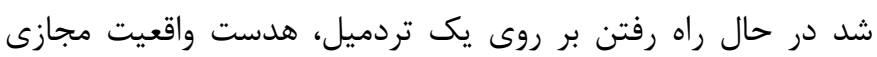
را به جشم كذاشته و تكاليف مجازى ارائه شده را انجام دهند. نتايج نشاندهنده تاثير مثبت واقعيت مجازى بر بهبود توجه و كاركردهاى

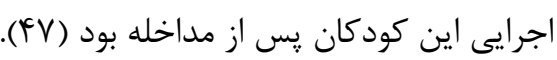

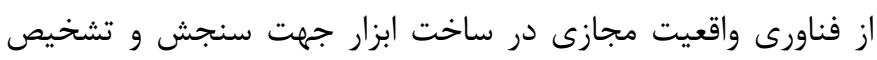

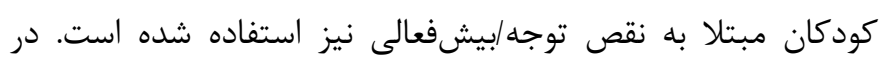

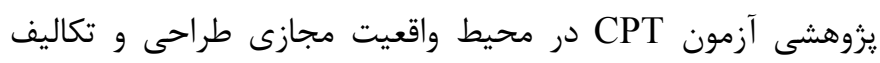

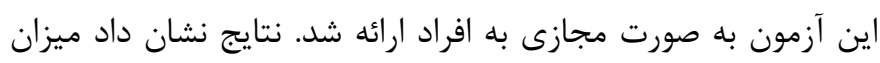

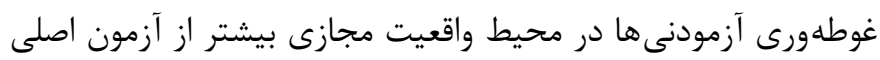
است و توجه انتخابى در محيط مجازى نسبت به شرايط واقعى بيشتر

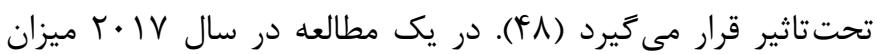
اثربخشى درمان مبتنى بر واقعيت مجازى و ذهن آكاهى بر بزر دَسالان 
تدوين بسته بومى نرمافزارى مبتنى بر تصاوير • ؟ب درجه حقيقى براى

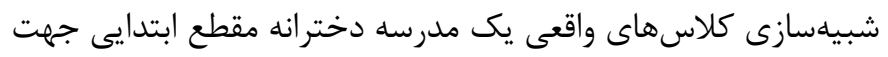
كاهش حساسيت به عوامل حواسيرتى و بهبود نشانكان نقص توجها

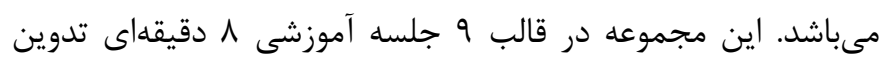

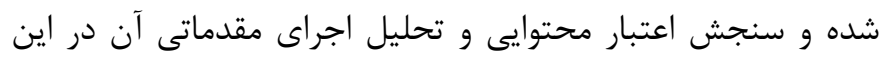

$$
\text { يزوهش صورت گرفته است. }
$$

\section{روش كار}

يزوهش حاضر از نوع اعتبارسنجى بود. در مرحله نخست، براى بررسى

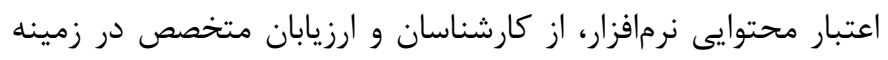

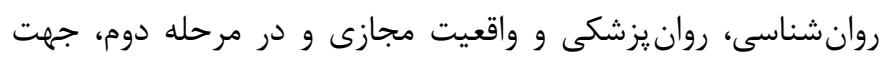

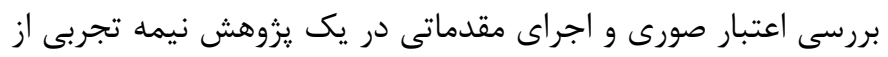

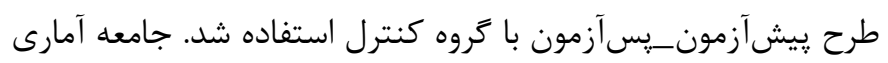

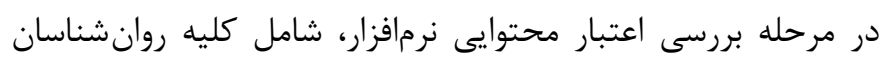

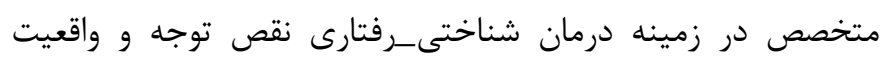

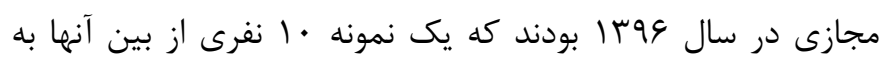

روش هدفمند انتخاب شدند.

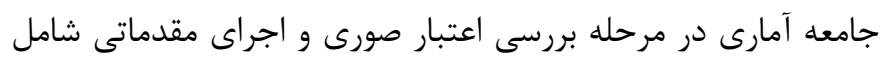

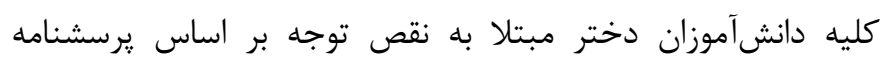
SNAP-IV

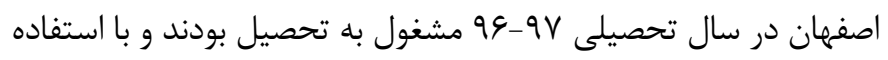

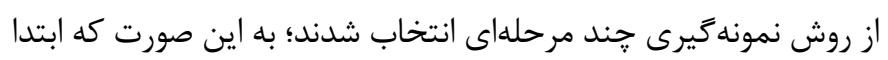

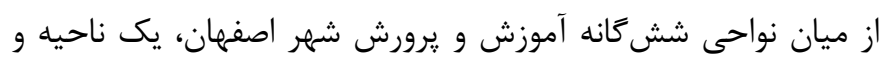

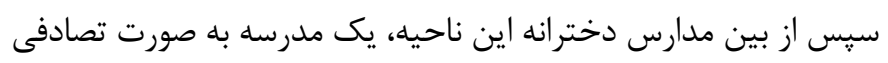

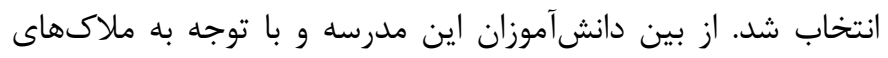

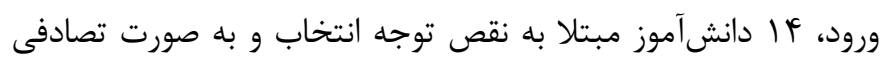

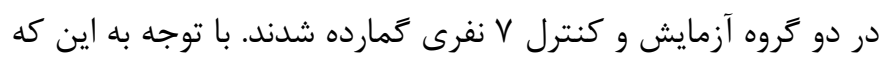

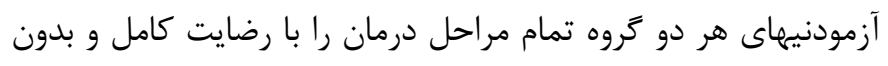

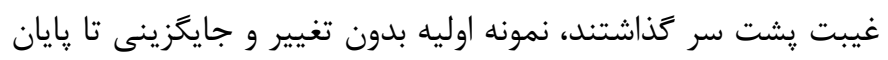
جلسات درمانى حفظ شد. ملاكهاى ورود عبارت بودند از كسب نمره

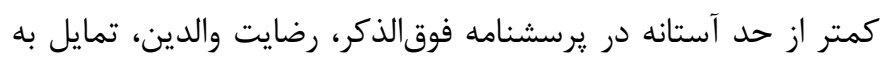

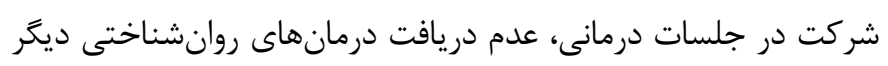

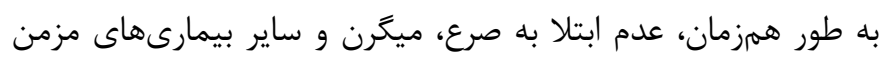

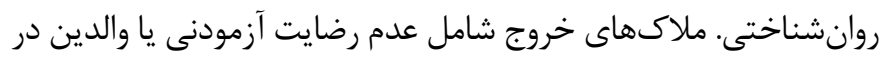

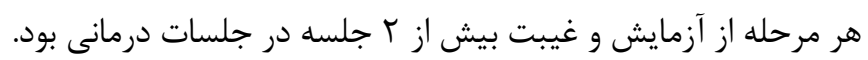

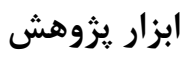
الف) ضبط و يخش تصاوير پانوراميك: در اين يزوهش از دوربين
صورت دلخواه و همينطور تعامل و بازىوارسازى (Gamification)

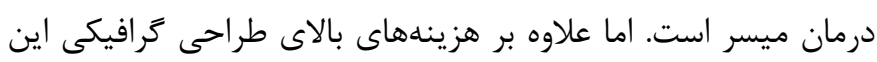

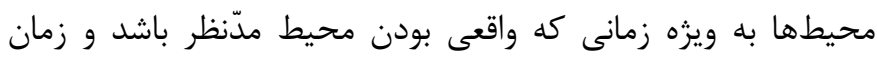

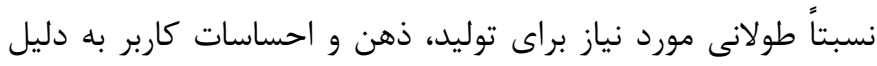

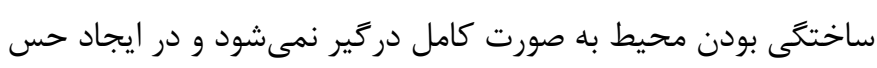

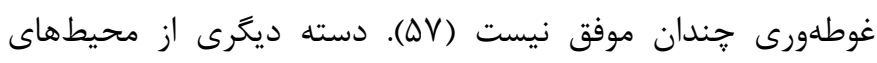

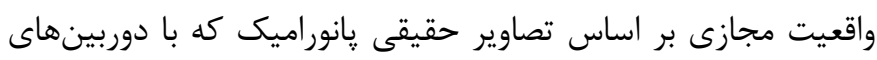

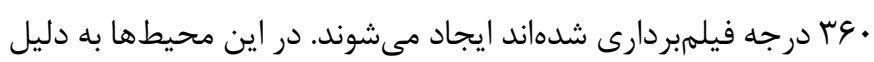

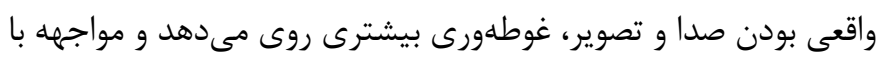

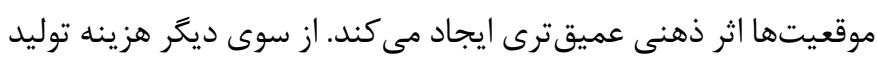

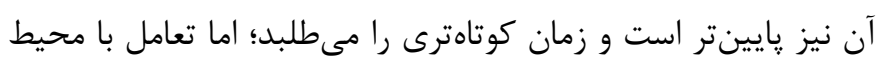

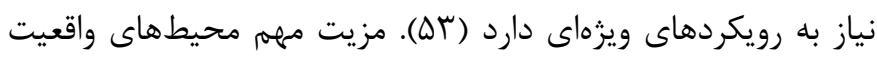

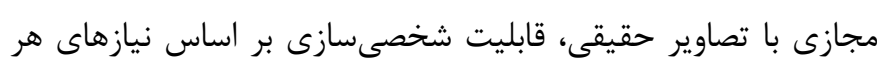

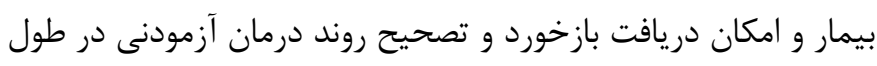
جلسات درمان با هزينه و زمان كم است.

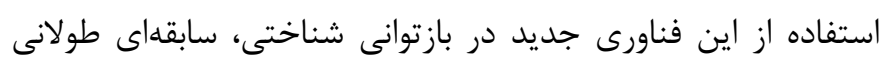

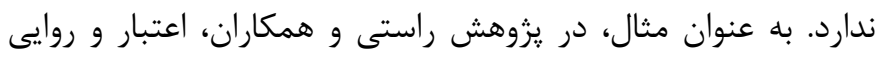

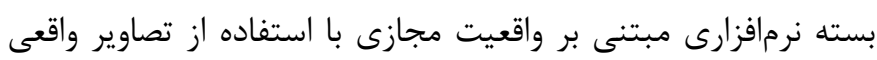

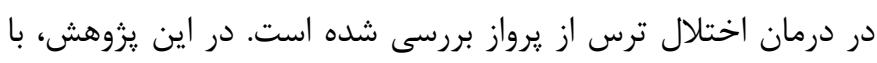

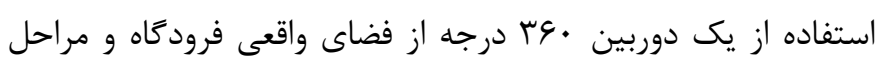

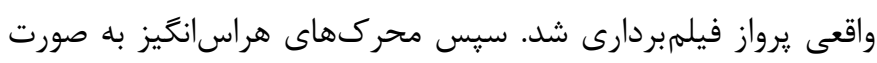

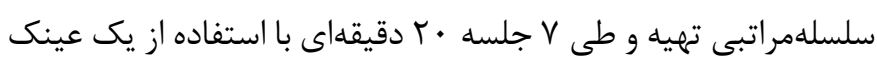

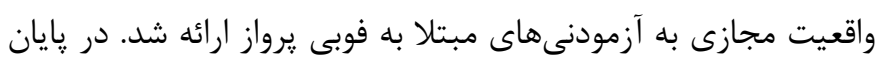

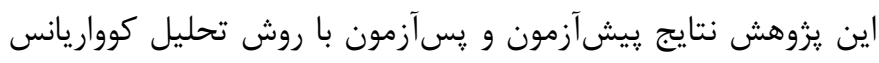

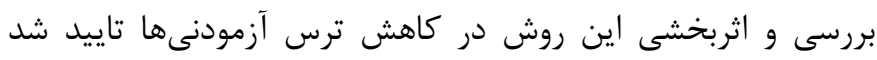

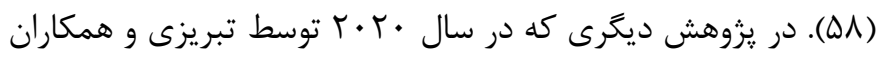

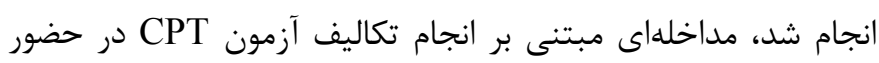

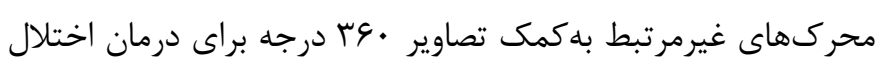

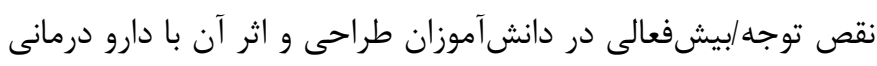

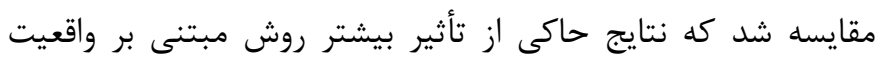

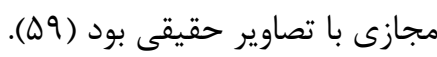
روند كلى درمانهاى رفتارى و شناختى نقص توجه، تلاش براى بـى كاهش

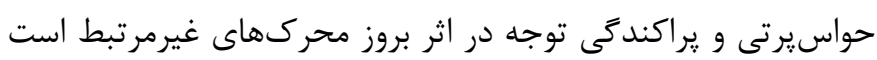

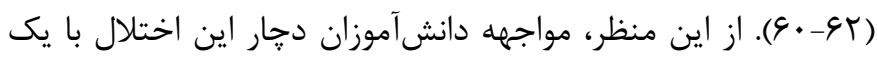
محيط واقعى كلاس درس در حضور عوامل مزاحم و تلاش براى متمركز

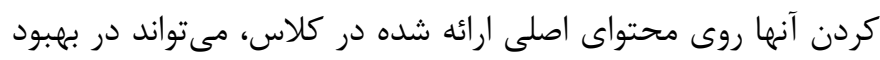

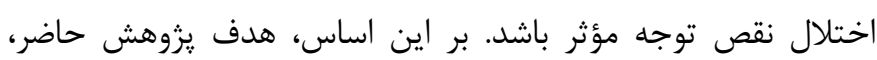


نقص توجه منجر شود (9). ويزَىى مهم فناورى واقعيت مجازى با تصاوير حقيقى، تداعى محيطهاى واقعى و ايجاد توانايى تربيت ذهن در محيطهاى شبه واقعى است كه مىتواند به همان اثرات آموزش و درمان در محيطهاى واقعى منجر شود. بر اساس اين قابليتها و با مشورت متخصصان حوزه توجه و نيز معلمان مقطع ابتدايى، \ل اسناريو از اتفاقات روزمره كلاسهاى درس مدارس ابتدايى دخترانه تدوين و فيلمبردارى

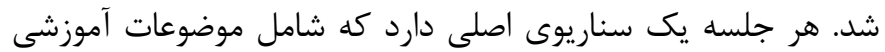
ماند تدريس معلم، خواندن از روى كتاب، آزمايش، كشيدن نقاشى،

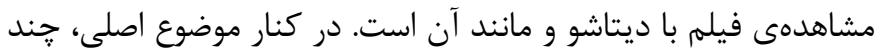
محرك نامرتبط مانند به صدا در آمدن در كلاس يا موبايل معله، سر و

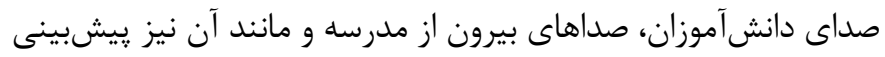
شده است كه به مرور از نظر تعداد و شدت ايجاد حواسيرتى، افزايش

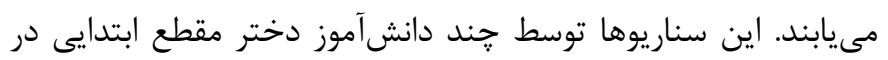

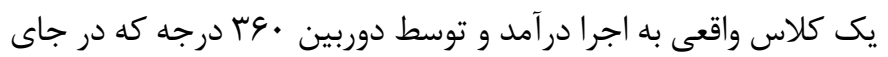

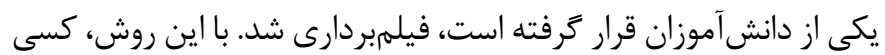
كه اين فيلم را مىبيند، خود رادر جاى دوربين مشاهده كرده و كاملاً در جوّ كلاس واقعى غوطهور مىشود. شكل الر را ببينيد. از آنجا كه هنكام مشاهده فيلمهاى • عب درجه، مخاطب كاملاً در محيط غوطهور است، كاهى سيستم عصبى به عدم تطابق آنجه مشاهده مى كند و آنجه از حسكر هاى زيستى بدن دريافت مى كند واكنش نشان داده و

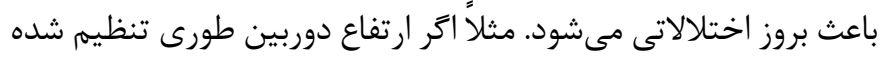

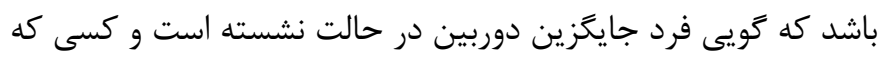

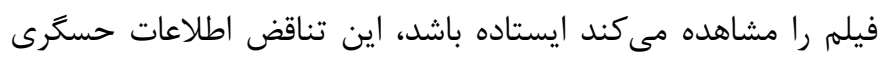
ممكن است سيستم حفظ تعادل بدن را دجار مشكل كند و باعث سر يَيه و حالت تهوع شود. براى جلوگيرى از اين مشكل، طول هر فيلم حداكثر ه دقيقه در نظر كرفته شده است. در نهايت \1 قطعه فيلم مزبور پس از تدوين و ويرايش، بهصورت يك بسته نرمافزارى درآمد.

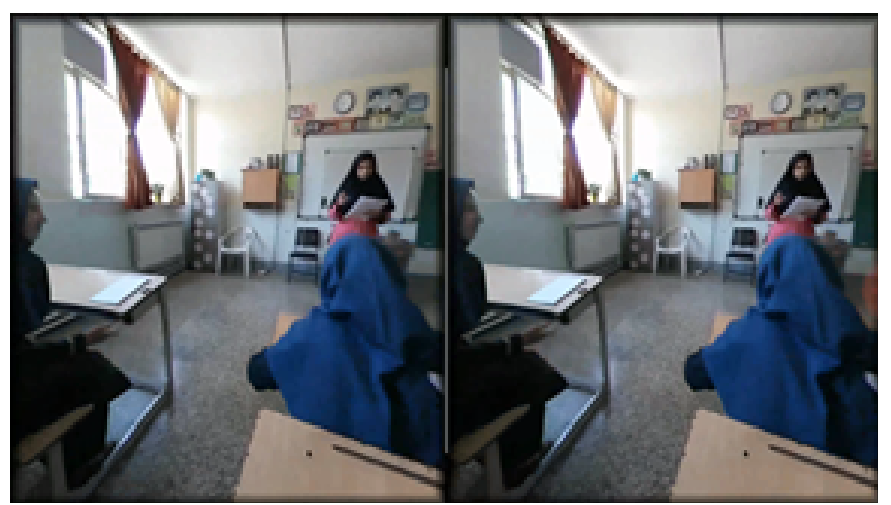

• ع درجه Gear360 سامسونغ براى فيلهبردارى استفاده شده است. كه تصوير كل فضاى دور خود را به كمك دو لنز •11 درجه با كيفيت ها مكايِيكسل ثبت مى كند (ب/ع). فيلمهاى ضبط شده به كمك

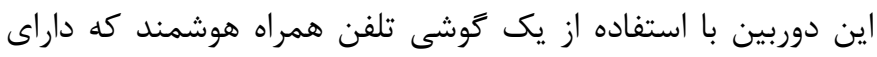
زيروسكوٍ باشد و يك هدست واقعيت مجازى كه كوشى داخل آن قرار

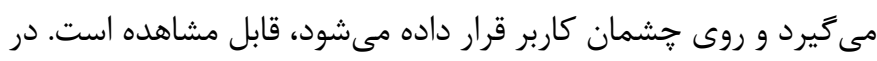
اين وضعيت، كاربر با كرداندن سر خود به هر طرف، تصويرى كه دوربين در همان زاويه ضبط كرده است را مشاهده مى كند و به اين ترتيب يك نه تجربه واقعى صوتى و تصويرى از محل ضبط فيلم به وى ارائه مىشود. در اين وضعيت، مشاهدهكنده خود را در محل واقعى دوربين هنحام فيلمبردارى مىبيند و غوطهورى كامل حاصل خواهد شد. ب) يرسشنامه SNAP-IV: اين يرسشنامه اختلال نقص توجها

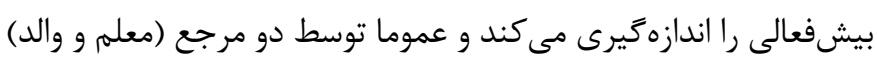

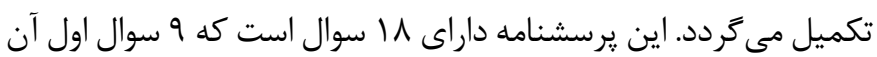

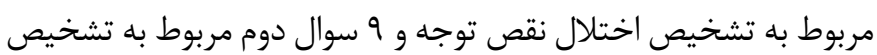
اختلال بيشفعالى است. بنابراين با كمك اين مقياس سه نوع تشخيص لته

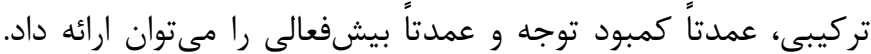
طيف درجابندى بر مبناى مقياس ليكرت از صفر تا س صورت مى گيرد و براى محاسبه نمره، جمع امتياز فرد در كل يرسشنامه به عدد ل1 ا و در هر كدام از خردهمقياسها به عدد 9 تقسيم مىشود. ضريب يايايى اين

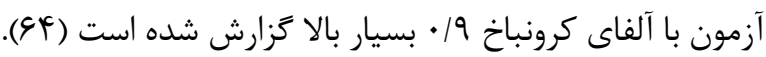

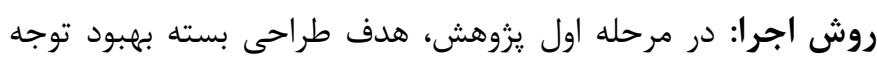

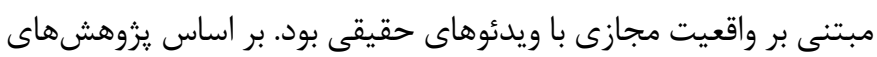

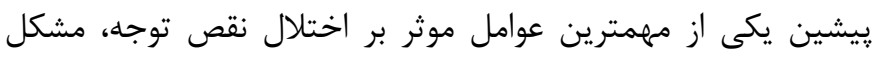
فرد در توجه انتخابى و تمركز روى يك موضوع خاص در حضور عوامل نامرتبط است (V، DQ). بنابراين به دست آوردن توانايى ذهنى در كنترل ورود عوامل محرك و تصفيه عوامل نامربوط مىتواند به بهبود اختلال

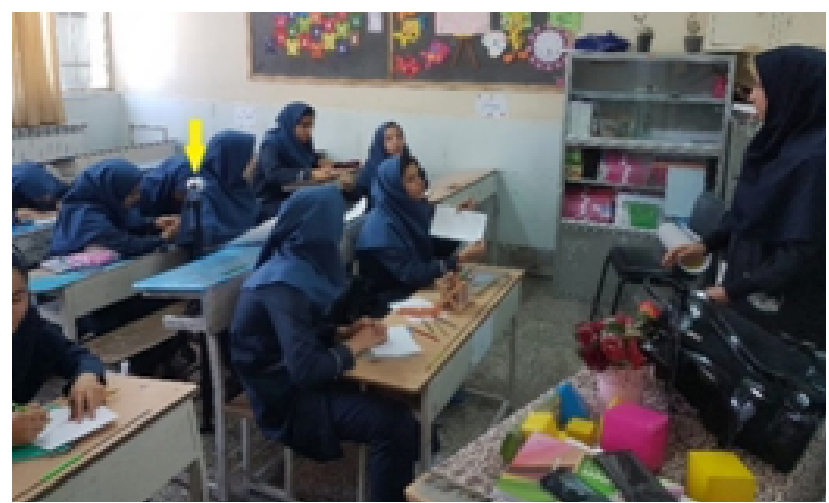
شكل (. الف) نمونهاى از ضبط يك سناريو در كلاس (به جايگاه دوربين دقت كنيد). ب) نمونه تصوير مشاهده شده روى هدست واقعيت مجازى 
f) سؤالات بعد از فيلم در جلسات ابتدايى سادهتر و شامل جزييات محيط است و به مرور بر روى موضوعات اصلى درس متمركز مى دشود.

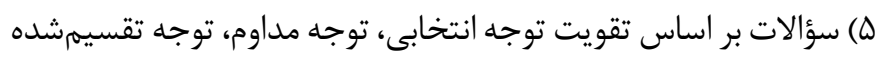

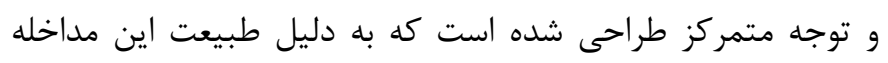

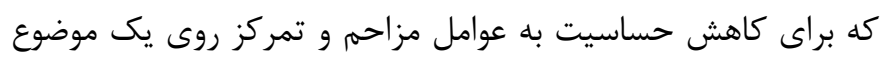
طراحى شده است، تعداد سؤالات مرتبط با توجه انتخابى بيشتر است.

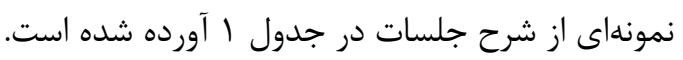

اصول طراحى اين بسته نرمافزارى به صورت زير است: () موضوع اصلى فيلم در جلسات ابتدايى سادهتر و نيازمند توجه كمتر

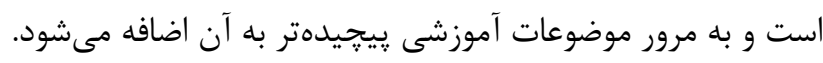

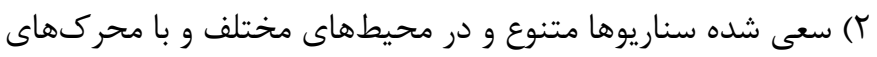

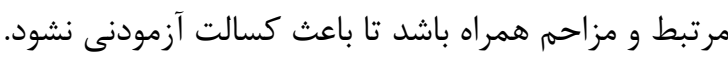

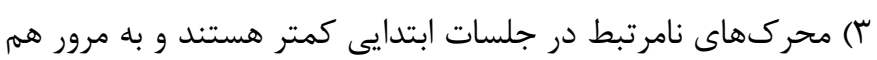

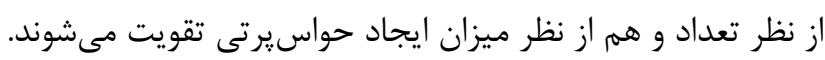

جدول ا. نمونه جلسات يروتكل درمان نقص توجه مبتنى بر واقعيت مجازى

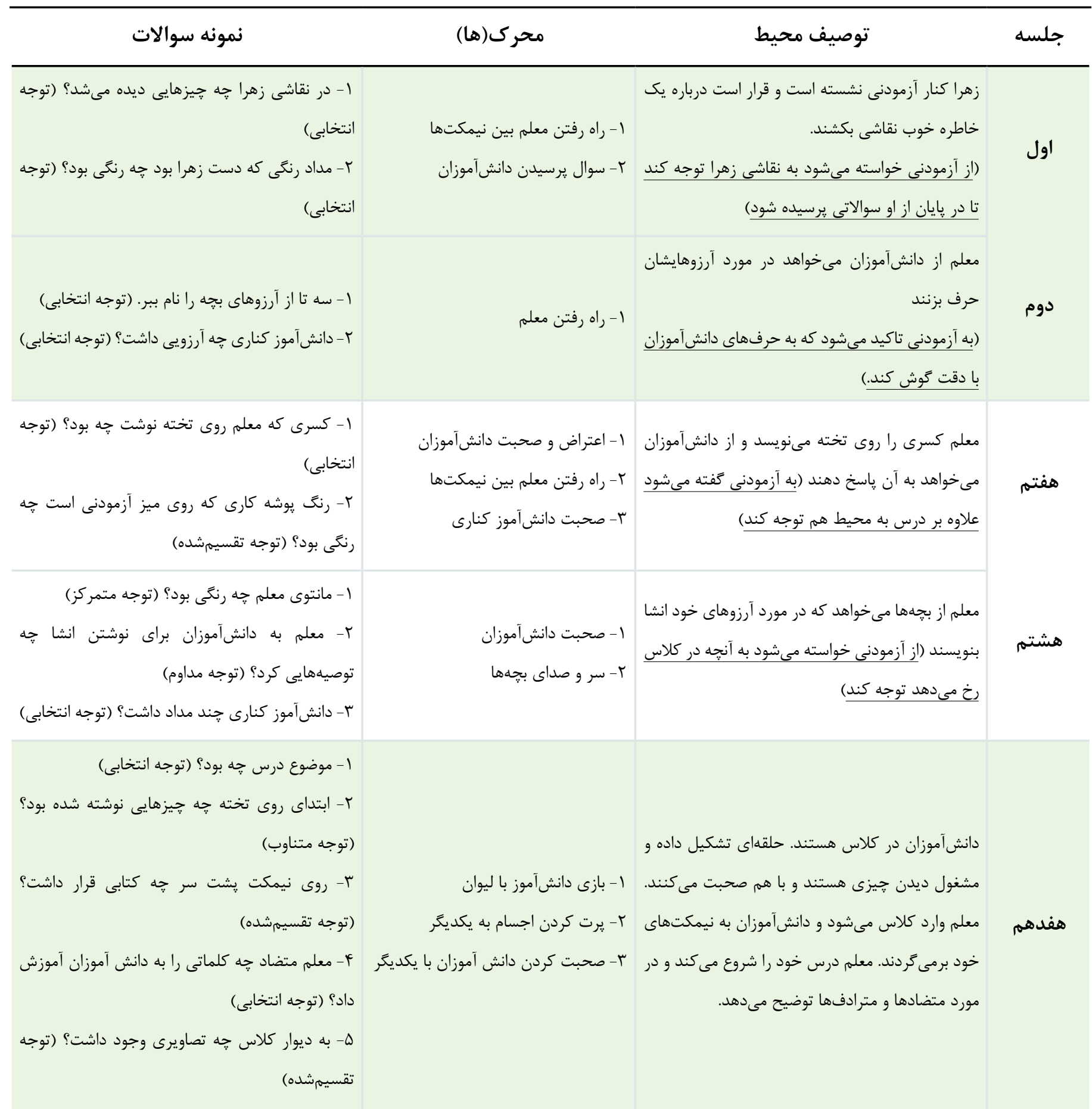


1- روى اسلايد جه جيزى نمايش داده شده بود؟ (توجه

$$
\text { تقسيمشده) }
$$

دانشىآموزان در كلاس نشسته و مشغول درست كردن

ץ- معلم روى وايتبورد קهه جيزى نوشت؟ (توجه

$$
\text { (- صحبت كردن دانش آموزان انتخابى) }
$$

ץ- قيجيى جه رنكى بود؟ (توجه متمركز و تقسيم شده)

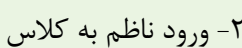
كاردستى و صحبت كردن هستند. تصوير درس مورد ץ- به ديوار كلاس جه جيزهايى ديده مى شد؟ (توجه نظر بر روى يروزكتور نمايش داده شده است. معلم ياى رَى تخته مىرود، تخته را پاك مى كند و شروع به نوشتن هجدهم مطالبى مى كند. ناظم در كلاس را مىزند و معلم را به بيرون از كلاس فرامى خواند.

جلسات، عوامل حواسيرتى و ميزان دشوارى تكاليف آورده شدهاند. اين يرسشنامه در اختيار ه نفر از متخصصين حوزه روانشناسى و ه نفر از صاحبنظران و متخصصين در حوزه طراحى و شبيهسازى محيط هاى واقعيت مجازى قرار كرفت و يس از اعمال نظرات اصلاحى آنها، اثربخشى روش مورد نظر از طريق محاسبه ضريب توافق كايا

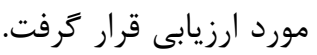

جهت تعيين اعتبار محتوايى نرمافزار، فرم ارزيابى كلى V سؤالى محقق ساخته با طيف ليكرت ه ززينهاى در اختيار متخصصين قرار كرفت (جدول ץ). اين پرسشنامه در دو قسمت گردآورى شده است. كويههاى ا تا ب به بررسى نرمافزار از بعد فنى و ارزيابى كيفيت

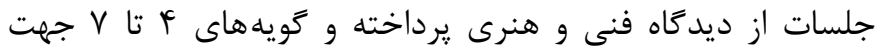
بررسى نرمافزار از بعد روانشناختى و بر اساس سنجش محتواى

جدول r. يرسشنامه محققساخته جهت ارزيابى اعتبار محتوايى بسته نرمفزارى مبتنى بر واقعيت مجازى

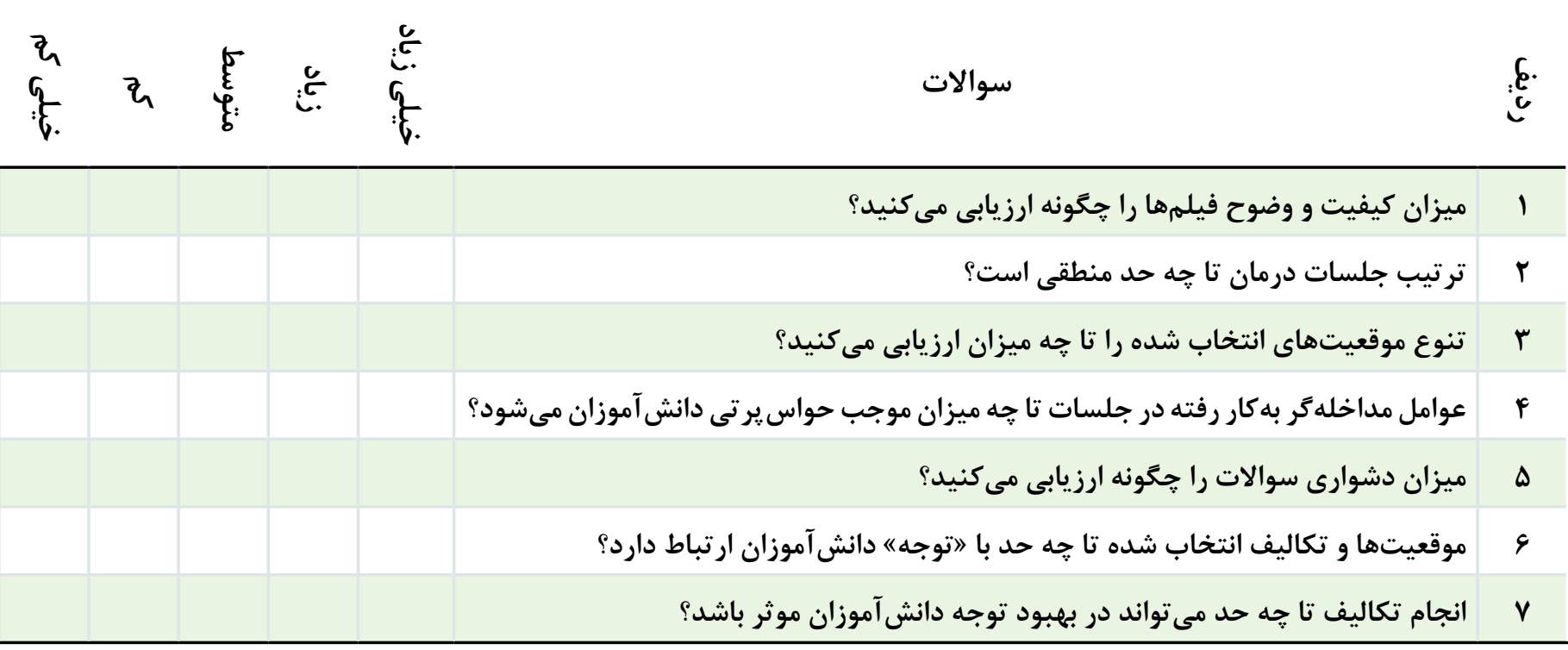

مربوطه است. گروه كنترل در ليست انتظار قرار گرفت تا يس از پايان

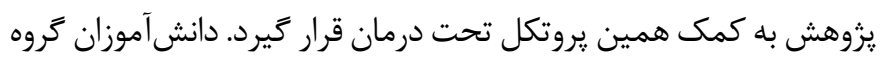

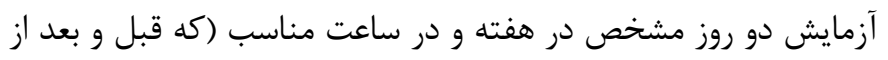

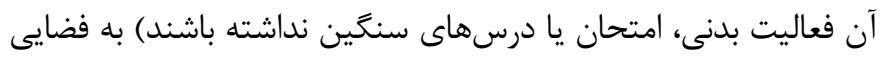

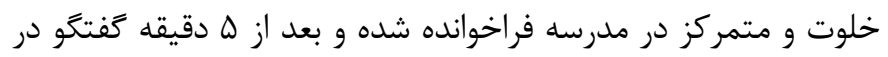
مورد موضوعات متفرقه به جهت تخليه و آرامش ذهنى، هدست را روى سر كذاشته و يك قطعه فيلم را مشاهده مى كنند. فضاى ييرامون دانشى آموز
به منظور تعيين اعتبار صورى و اجراى مقدماتى نرمافزار، يك نمونه محدود † ا نفرى از افراد مبتلا به نقص توجه بر اساس ملاكىهاى ورود به شيوه نمونهَيرى در دسترس انتخاب و به طور تصادفى در دو گروه آزمايش و

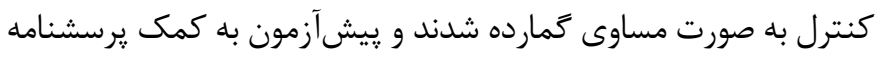
SNAP-IV جلسهاى (هر هفته دو جلسه) بيشبينى شد كه هر جلسه شامل مشاهده دو فيلم پانوراميك به كمك هدست مخصوص و پاسخ به يرسشهاى 
از جاى خود حركت كرده يا دستش رابراى گرفتن شيئى دراز كند كه در اين وضعيت نبايد خطرى متوجه او باشد. شكل r را ببينيد.
بايد خالى از موانع و اشياء در معرض سقوط باشد؛ جون غوطهورى در فيلمهاى يُانوراميك زياد است و ممكن است آزمودنى به صورت ناخودآكاه

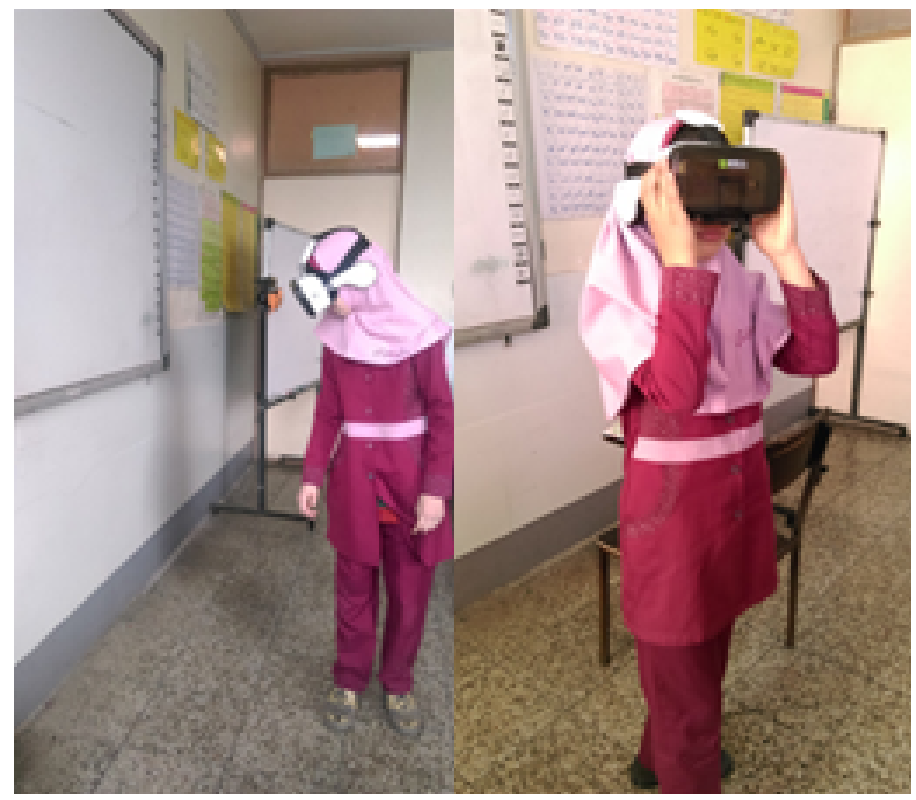

شكل r. اجراى مداخله روى آزمودنىها

ميتوان ميزان توافق دو يا جند اندازهگيرى (توسط دو نفر يا دو ابزار يا در دو مقطع زمانى) را ارزيابى كرد. ضريب كايا بين صفر تا يك متغير است كه هر جهه به ا نزديكتر باشد، نشانگر توافق بيشتر ارزيابان است (SV). به اين منظور، يرسشنامه ذكر شده در اختيار •. نفر از متخصصين حوزه روانشناسى و طراحى و شبيهسازى محيطهاى واقعيت مجازى قرار گرفت و ضريب توافق ارزيابان با استفاده از ضريب

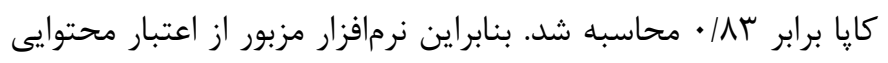
بالايى برخوردار است. ميانگين درصد ياسخهاى صحيح آزمودنىها بر حسب جلسات در شكل

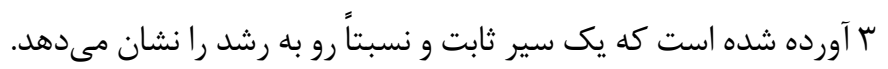
با توجه به پيجِيدهتر شدن محتواى ارائه شده در جلسات متوالى و نيز

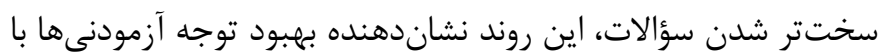
يn رفتن روند مداخله است.
بعد از مشاهده فيلم، دانش آموز هدست را از سر برداشته و بعد از كذشت يك دقيقه به جهت بازگشت به فضاى واقعى و متمركز شدن، از او سؤالاتى در مورد جزييات و محتواى فيلم (به ويزه موضوعات آموزشى مطرح شده) يرسيده و ياسخهاى او ثبت مىشود. بعد از يك فرصت ه دقيقهاى به منظور ايجاد تمركز و نيز ييشگيرى از بروز مشكلات سر گيجه و حالت تهوع، فيلم دوم به همين روال يخش خواهد شد.

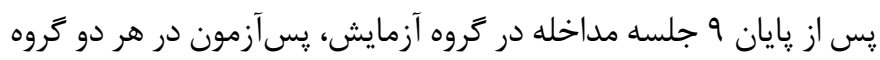
با يرسشنامه SNAP-IV انجام شد. براى بررسى اثربخشى بسته آموزشى لِّى طراحى شده از آزمون منويتنى و نرمافزار SPSS-23 استفاده شد.

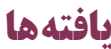

در اين مطالعه به جهت تعيين اعتبار محتوايى بسته درمانى طراحى شده از ضريب كايا كوهن استفاده شده است. از طريق اين ضريب،

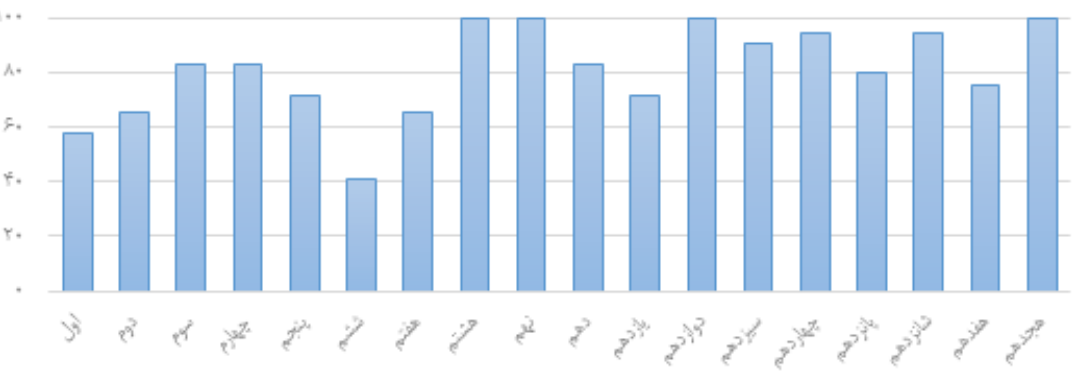

شكل r. ميانگين درصد پاسخهاى صحيح آزمودنى بر حسب جلسات 
گروه آزمايش در مقايسه با كروه كنترل در مرحله يسآزمون به ميزان قابلتوجهى كاهش يافته است. همرنين نتايج به دست آمده از آزمون

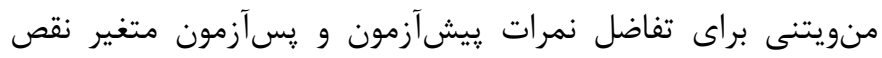
توجه، نشاندهنده تفاوت معنادار اين دو گروه قبل و بعد از مداخله

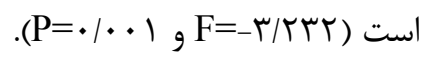

جدول r نتايج حاصل از آزمون منويتنى براى تفاضل نمرات نقص

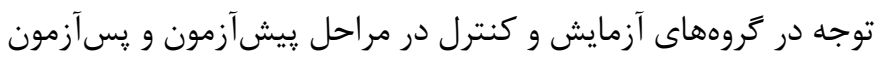

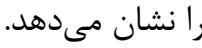

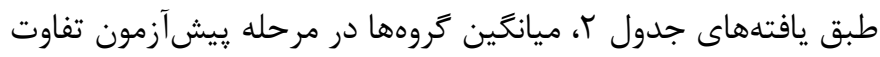
قابل ملاحظهاى با يكديگر ندارند. اما ميانگين نمرات نقص توجه در

جدول r. ميانگين و انحراف معيار متغير نقص توجه و نتايج آزمون منويتنى در گروههاى مورد مطالعه

\begin{tabular}{|c|c|c|c|c|c|}
\hline $\mathbf{P}$ & $\mathbf{F}$ & ميانگين « يس آزمون آنحراف معيار & ميانگين & كروه & \\
\hline \multirow{2}{*}{$\cdot 1 \cdot \cdot 1$} & \multirow{2}{*}{ TH/TMT } & •/ $/ \mathrm{Fr}_{ \pm} \cdot / \cdot \Delta r$ & $\cdot \mid \Delta \Delta V \pm \cdot / \cdot r$ & آزمايش & \multirow{2}{*}{ متغير } \\
\hline & & $\cdot|\Delta \wedge \varepsilon+\cdot| \cdot \mid \cdot$ & $\cdot|\Delta \& \& \pm \cdot| \cdot V \cdot$ & كنترل & \\
\hline
\end{tabular}

درمان با واقعيت مجازى، سطح دشوارى موقعيت قابل كنترل است و مىتواند بر اساس نيازهاى هر فرد تغيير كند و اين موضوع باعث مىشود يادگيرى با سرعت و نتيجه مطلوبى انجام شود. از سوى ديخر ايجاد موقعيتهاى مواجههاى براى درمان انواع فوبيا يا مقابله با محركهاى ضد توجه به كمك فناورى واقعيت مجازى با هزينه كم و فرآيند توليد كوتاه امكان يذير خواهد بود. در سالهاى اخير يزوهشگران به بررسى كاربرد فناورى واقعيت مجازى در درمان و بهبود اختلال نقص توجه يرداختهاند. شبيهسازى كلاس درس با كمك واقعيت مجازى يكى از روشهاى استفاده از اين تكنولوزى در درمان نقص توجه/بيشفعالى است. نيمكت، معلم، دانشآموزان و عوامل مزاحم و ايجادكننده حواسيرتى در محيط واقعيت مجازى همخَى به صورت سه بعدى شبيهسازى شدهاند. كودى با بر جشم حذاشتن عينك واقعيت مجازى وارد محيط شده و در اطراف خود كلاس، معلم، دانش آموزان و تعدادى عوامل مزاحم مى بيند و معلم مجازى از وى مى خواهد در حضور عوامل حواسيرتى تعدادى تكليف مشخص را انجام دهد. نتايج اين يزوهش ها نشان مى دهد قرار گرفتن در محيط واقعيت مجازى و القاى حس غوطهورى باعث مىشود آزمودنى نسبت به صحبتهاى معلم مجازى حساستر شده و توجه كمترى به عوامل مزاحم كرده و در نتيجه زمان پاسخ به تكاليف در وى نسبت به به درمان هاى سنتى كوتاهتر و اثربخشى آن بيشتر شود (99). شبيهسازى موقعيتهاى شبه واقعى براى سنجش، ارزيابى، آموزش و و و درمان اختلال نقص توجه به سرعت در حال بيشرفت است. در محيط واقعيت مجازى اين امكان فراهم است كه بر اساس نيازهاى خاص هر آزمودنى محركها و عوامل حواسيرتى ويزهاى طراحى شود تا توجه
اختلال نقص توجه يكى از عوامل كندى يا عدم پيشرفت تحصيلى

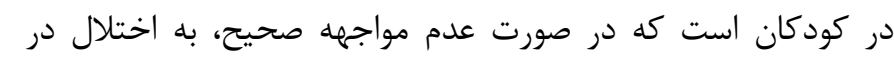
يادگيرى و ساير فرآيندهاى شناختى و ترك تحصيل منجر خواهد شد. Barkley است كه توسط رفتار نايايدار و متغير ناشى از عدم (Irregularity) تعادل بيوشيميايى در مغز ايجاد مىشود. اين عدم تعادل بيوشيميايى به عنوان يك عامل مشكل ساز در شروع و حفظ توجه روى يك كار در نظر كرفته مى شود كه به تبع آن انجام وظايف روزانه با مشكل مواجه مىشود (V). تلاشهاى فعلى در درمان اين اختلال عموماً بر تغيير و تعديل همبستههاى عصبى، زيستشيميايى، رفتارى، شناختى، روانى و اجتماعى يا درمانهاى تركيبى معطوف شدهاند. يكى از راهكارهاى بهبود توجه، افزايش توانايى ناديده گرفتن محرك هاى متفرقه و تمركز روى موضوع هدف است. اين روش در اجرا به ويزه در محيطهاى اختصاصى مانند كلاس درس يا آزمايشعاه، با مشكلات و هزينههاى زيادى روبرو است كه انجام آن را عملاً غيرممكن مىسازد. واقعيت مجازى، نوعى فناورى براى ايجاد تعامل بين انسان و رايانه است كه با تحريك حواس بينايى، شنوايى و لامسه و حتى بويايى و جشايى در نمونههاى جديد، باعث القاء حس حضور واقعى فرد در محيط مجازى مىشود. يكى از ويزَى هاى اين فناورى، غوطهور ساختن فرد در دنياى شبه واقعى است؛ به طورى كه ذهن و جسم فرد به گونهاى واكنش نشان مىدهد كه گمان مىرود در محيط واقعى قرار دارد. به كمك اين ويزگ ويزه زيرشاخههاى مرتبط با درمان وآموزش، ايفا كند (\$^). در جريان 
مجازى با تصاوير حقيقى بر اساس مداخله مبتنى بر آزمون CPT طراحى

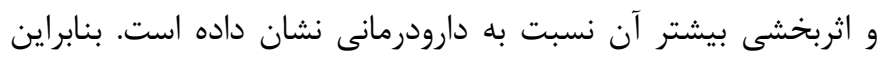

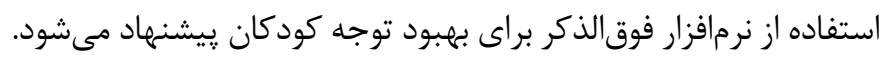

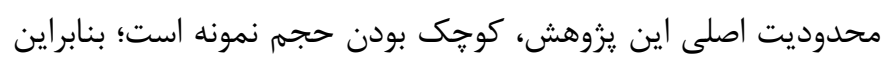

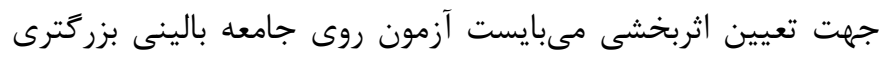

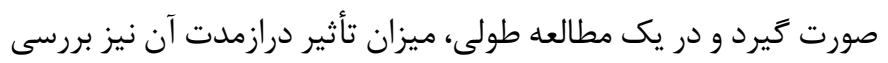

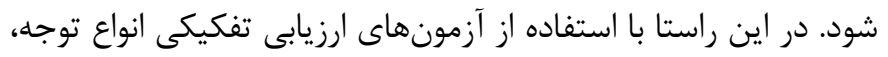
مىتوان ميزان اثركذارى اين نرمافزار روى توجههاى مختلف را جداكانه بررسى كرد. محدوديت ديكر اين است كه به جهت رعايت همزاتيندارى

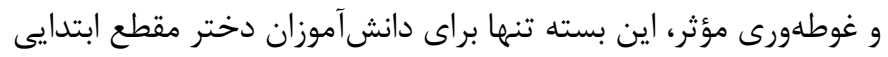

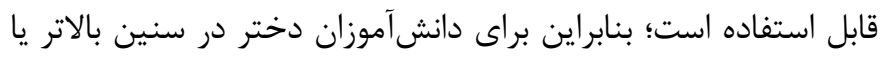

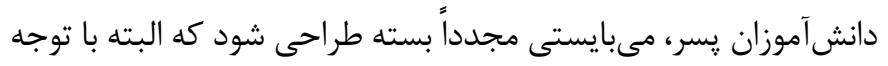

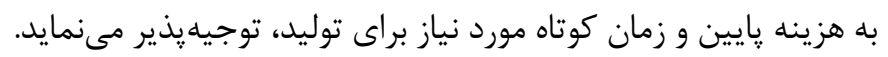

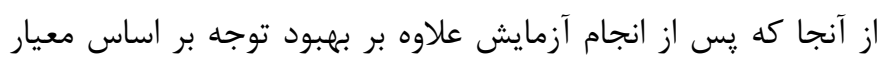
SNAP-IV

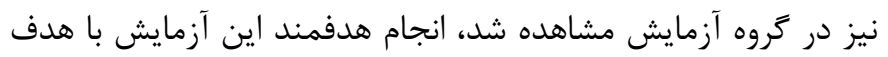

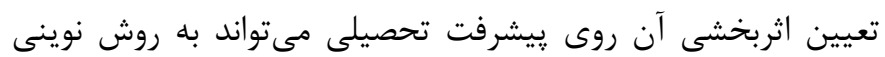

$$
\text { براى ييشرفت تحصيلى منجر شود. }
$$

در پايان، درمانكر بايد به اين نكته توجه داشته باشد كه مشاهده

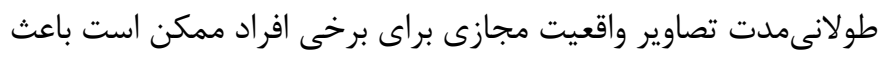

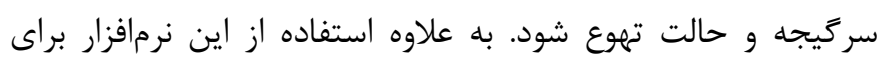
مبتلايان به صرع و ميكرن توصيه نمى حئهود.

\section{نتيجه كيرى}

يكى از كاربردهاى واقعيت مجازى استفاده از اين فناورى در مداخلات

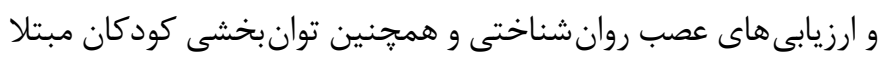

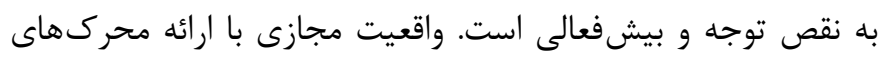

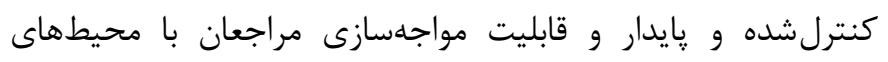

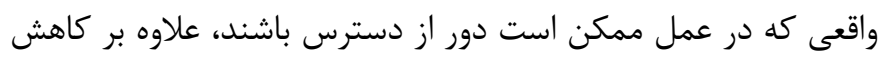

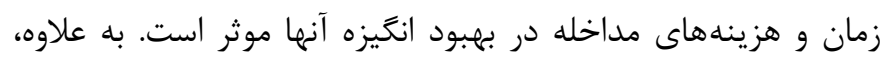

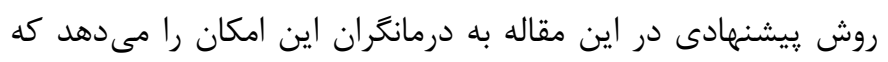

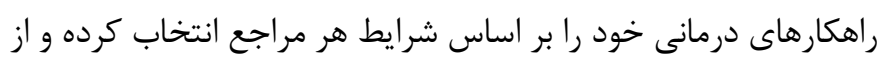
اين طريق مهارتهاى رفتارى و شناختى كودكان مبتلا به نقص توجه درانه و بيش فعالى بهبود دهند.

\section{تشكر و قدرهاذى} اين مقاله از پايان نامه مقطع كارشناسى ارشد مهندسى يزشكى مصوب
آزمودنى براى مدت طولانى ترى بر تكاليف حفظ شود (•V). زمانى كه

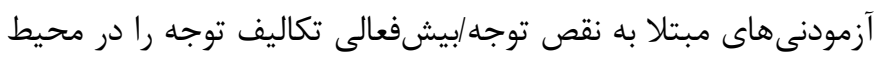

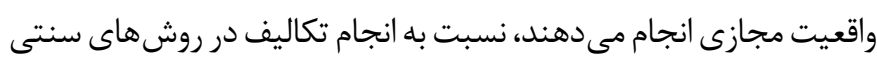

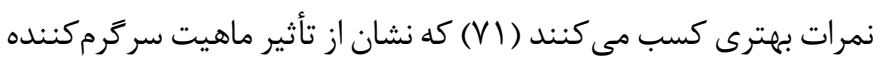

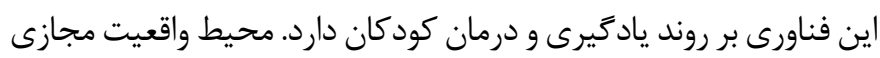

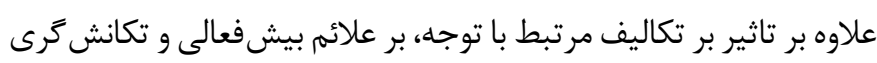

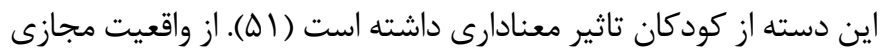
همجنين به عنوان يك روش درمان در بهبود نقص توجه، حافظه كارى

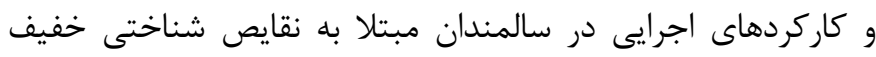

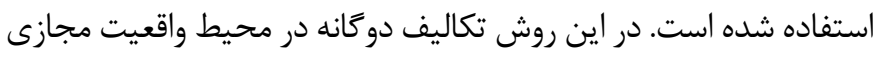

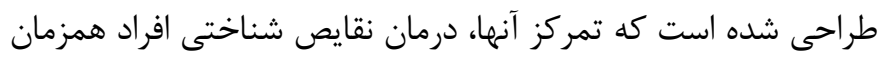

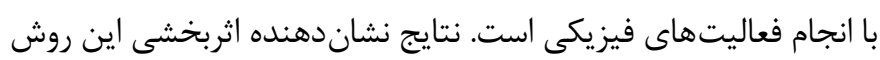

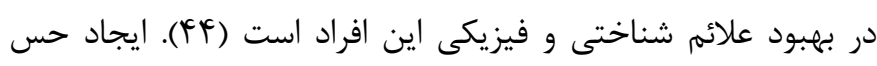

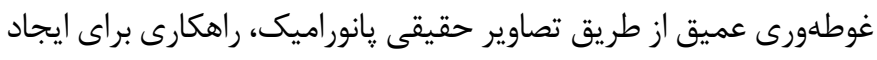

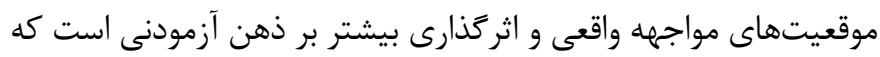

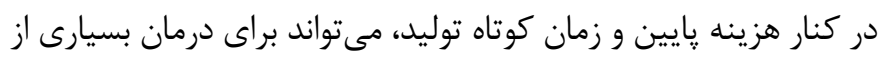
اختلالات شناختى مور استفاده قرار كيرد.

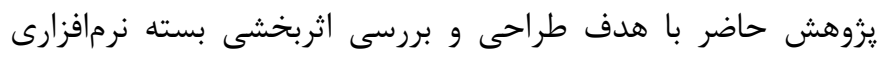

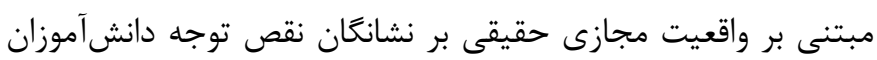

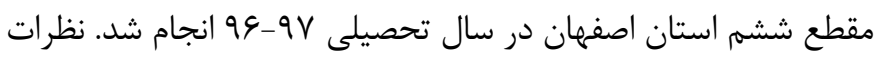
متخصصان مؤيد اعتبار محتوايى بسته مزبور است و مونان مقايسه نتايج

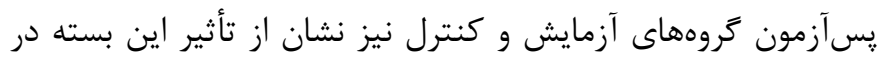

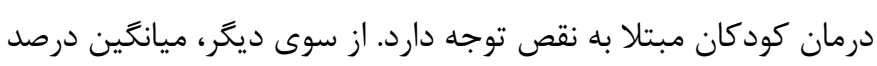

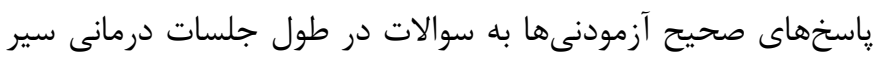

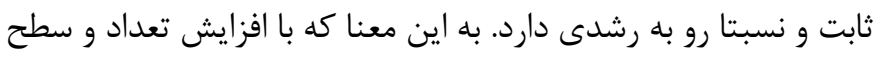
دشوارى سوالات در طى روند درمان، آزمودنىها توانستهاند توانايى خود

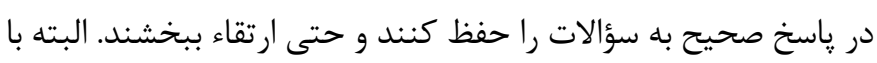

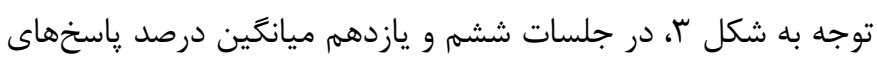

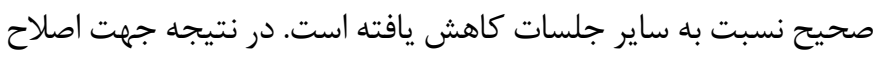
روش مورد نظر، سوالات مربوط به اين جلسات مورد ارزيابى مجدد قرار كرفته و سطح دشوارى آنها تعديل گرديد.

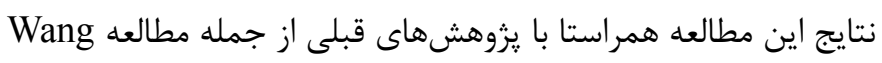

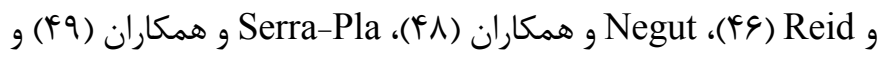

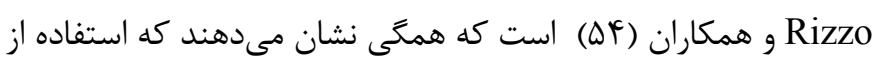
فناورى واقعيت مجازى مى تواند در درمان اختلال نقص توجه با با استفاده

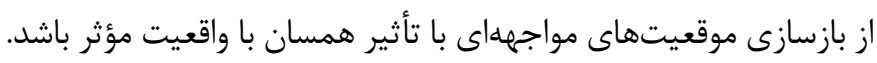

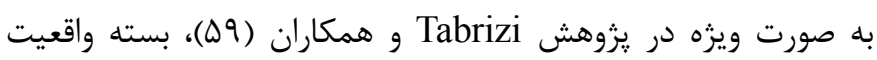


به جهت همكارى همه جانبه در فيلمبردارى و تدوين بسته موضوع يزوهش صميمانه قدردانى مى كنند.

\section{References}

1. Abdi A, Arabani Dana A, Hatami J, Parand A. The effect of cognitive computer games on working memory, attention and cognitive flexibility in students with attention deficit/hyperactivity disorder. Journal of Exceptional Children. 2015;14(1):19-

\section{3. (Persian)}

2. Niazi M. Attention deficit/hyperactivity disorder children training. Isfahan:Neveshteh Publication;2015. (Persian)

3. Seidman LJ. Neuropsychological functioning in people with ADHD across the lifespan. Clinical Psychology Review. 2006;26(4):466-485.

4. Sohlberg MM, Mateer CA. Cognitive rehabilitation: An integrative neuropsychological approach. New York:Guilford Publications;2017.

5. Yeh SC, Tsai CF, Fan YC, Liu PC, Rizzo A. An innovative ADHD assessment system using virtual reality. In 2012 IEEE-EMBS Conference on Biomedical Engineering and Sciences. 2012 Dec 17-19; Langkawi, Malaysia. IEEE. pp. 78-83. 6. Hardman M, Drew C, Egan W. Psychology and training exceptionality children's, society, school, and family. Alizadeh H, Gangi K, Yousefi Looyeh M, Yadegari F, translators. 7th ed. Tehran:Dangeh Publication;2007. (Persian)

7. Barkley RA, Murphy KR. Attention-deficit hyperactivity disorder: A clinical workbook. New York:Guilford Press;2006.

8. Breeze JM, Kirkham AJ, Marí-Beffa P. Evidence of reduced selective attention in schizotypal personality disorder. Journal of Clinical and Experimental Neuropsychology. 2011;33(7):776-784.

9. Mezzacappa E, Buckner JC. Working memory training for children with attention problems or hyperactivity: A schoolbased pilot study. School Mental Health. 2010;2(4):202-208.

10. Alizadeh H. Neurocognitive executive functions and their relationship with developmental disorders. Advances in Cognitive Sciences. 2007;8(4):57-70. (Persian)
در دانشعاه اصفهان با كد اخلاق IR.UI.REC.1397.106 استخراج شده است. نويسندگان از مركز نوآورى صنايع سرگرمى دانشعاه اصفهان

11. Chou IC, Lin CC, Sung FC, Kao CH. Attention-deficit hyperactivity disorder increases the risk of deliberate self-poisoning: A population-based cohort. European Psychiatry. 2014;29(8):523-527.

12. Arns M, Conners CK, Kraemer HC. A decade of EEG theta/ beta ratio research in ADHD: A meta-analysis. Journal of Attention Disorders. 2013;17(5):374-383.

13. Fabiano GA, Pelham WE, Gnagy EM, Burrows-MacLean L, Coles EK, Chacko A, et al. The single and combined effects of multiple intensities of behavior modification and methylphenidate for children with attention deficit hyperactivity disorder in a classroom setting. School Psychology Review. 2007;36(2):195-216.

14. Van der Oord S, Prins PJ, Oosterlaan J, Emmelkamp PM. Efficacy of methylphenidate, psychosocial treatments and their combination in school-aged children with ADHD: A meta-analysis. Clinical Psychology Review. 2008;28(5):783-800. 15. Committee on Quality Improvement, Subcommittee on Attention-Deficit/Hyperactivity Disorder. Clinical practice guideline: Diagnosis and evaluation of the child with attention-deficit/ hyperactivity disorder. Pediatrics. 2000;105(5):1158-1170.

16. Kaur KS, Pathak R. Play-based occupational therapy intervention on social skills in children with autism spectrum disorder and attention deficit hyperactivity disorder: A case series. The Indian Journal of Occupational Therapy. 2019;51(1):31-36. 17. Hadley RT, Hadley WH, Dickens V, Jordon EG. Music therapy: A treatment modality for special-needs populations. International Journal for the Advancement of Counselling. 2001;23(3):215-221.

18. Linehan MM, Cochran BN, Kehrer CA. Dialectical behavior therapy for borderline personality disorder. In Barlow DH, editor. Clinical handbook of psychological disorders: A step-by-step treatment manual. 4th ed. New York:Guilford Press;2001. pp. 470-522. 
19. DiGiorgio KE, Glass CR, Arnkoff DB. Therapists' use of DBT: A survey study of clinical practice. Cognitive and Behavioral Practice. 2010;17(2):213-321.

20. Berkovits MD, O’Brien KA, Carter CG, Eyberg SM. Early identification and intervention for behavior problems in primary care: A comparison of two abbreviated versions of parent-child interaction therapy. Behavior Therapy. 2010;41(3):375-387.

21. Chaffin M, Silovsky JF, Funderburk B, Valle LA, Brestan EV, Balachova T, et al. Parent-child interaction therapy with physically abusive parents: Efficacy for reducing future abuse reports. Journal of Consulting and Clinical Psychology. 2004;72(3):500-510.

22. Van Den Hoofdakker BJ, Nauta MH, Veen-Mulders LV, Sytema S, Emmelkamp PM, Minderaa RB, et al. Behavioral parent training as an adjunct to routine care in children with attention-deficit/hyperactivity disorder: Moderators of treatment response. Journal of Pediatric Psychology. 2010;35(3):317-326.

23. Tahiroglu AY, Celik GG, Avci A, Seydaoglu G, Uzel M, Altunbas H. Short-term effects of playing computer games on attention. Journal of Attention Disorders. 2010;13(6):668-676.

24. Sonuga-Barke E, Brandeis D, Holtmann M, Cortese S. Computer-based cognitive training for ADHD: A review of current evidence. Child and Adolescent Psychiatric Clinics. 2014;23(4):807-824.

25. Wilms IL, Petersen A, Vangkilde S. Intensive video gaming improves encoding speed to visual short-term memory in young male adults. Acta Psychologica. 2013;142(1):108-118.

26. Zeinali A, Souri A, Ashoori J. The Effect of computer games on sustaining attention and organisation ability of students with attention deficit disorder. Journal of Advances in Medical and Biomedical Research. 2016;24(102):90-100. (Persian)

27. Van Der Oord S, Prins PJ, Oosterlaan J, Emmelkamp PM. Efficacy of methylphenidate, psychosocial treatments and their combination in school-aged children with ADHD: A meta-analysis. Clinical Psychology Review. 2008;28(5):783-800.

28. Beer JS, Shimamura AP, Knight RT. Frontal lobe contributions to executive control of cognitive and social behavior.
In Gazzaniga MS, editor. The cognitive neurosciences. Cambridge:The MIT Press;2004. pp. 1091-1104.

29. Cannon RL. LORETA neurofeedback: Odd reports, observations, and findings associated with spatial specific neurofeedback training. Journal of Neurotherapy. 2012;16(2):164-167. 30. Niknasab F, Sheikh M, Hemayattalab R. The effect of neurofeedback and play therapy on symptoms of children with attention deficit hyperactivity disorder. Journal of Sabzevar University of Medical Sciences. 2018;25(4):563-571. (Persian) 31. Oftadeh Hall M, Movahedi, Y. The effectiveness of neurofeedback training on the improvement of continuous attention. Social Cognition. 2016;5(1):9-19. (Persian)

32. Vosooghifard F, Alizadeh Zarei M, Nazari MA, Kamali M. The effect of neurofeedback training and neurofeedback with occupational therapy based on cognitive rehabilitation on executive functions in autistic children. Journal of Modern Rehabilitation. 2013;7(2):28-34. (Persian)

33. Hashemian Nejad F, Veysi N, Shirkavand N, Ashoori J. Comparing the effectiveness of neurofeedback training and computer games on continuous attention and planning ability in students with attention deficit disorder. Journal of Arak University of Medical Sciences. 2015;18(8):81-92. (Persian)

34. McCann RA, Armstrong CM, Skopp NA, Edwards-Stewart A, Smolenski DJ, June JD, et al. Virtual reality exposure therapy for the treatment of anxiety disorders: An evaluation of research quality. Journal of Anxiety Disorders. 2014;28(6):625-631.

35. Morina N, Ijntema H, Meyerbroker K, Emmelkamp PM. Can virtual reality exposure therapy gains be generalized to real-life? A meta-analysis of studies applying behavioral assessments. Behaviour Research and Therapy. 2015;74:18-24. 36. Jekel K, Damian M, Wattmo C, Hausner L, Bullock R, Connelly PJ, et al. Mild cognitive impairment and deficits in instrumental activities of daily living: A systematic review. Alzheimer's Research \& Therapy. 2015;7(1):17.

37. Wallach HS, Bar-Zvi M. Virtual-reality-assisted treatment of flight phobia. The Israel Journal of Psychiatry and Related Sciences. 2007;44(1):29-32. 
38. Garcia-Palacios A, Hoffman H, Carlin A, Furness Iii TA, Botella C. Virtual reality in the treatment of spider phobia: A controlled study. Behaviour Research and Therapy. 2002;40(9):983-993.

39. Klinger E, Bouchard S, Légeron P, Roy S, Lauer F, Chemin I, Nugues P. Virtual reality therapy versus cognitive behavior therapy for social phobia: A preliminary controlled study. $C y$ berpsychology \& Behavior. 2005;8(1):76-88.

40. Wald J, Taylor S. Efficacy of virtual reality exposure therapy to treat driving phobia: A case report. Journal of Behavior Therapy and Experimental Psychiatry. 2000;31(3-4):249-257.

41. Marco JH, Perpina C, Botella C. Effectiveness of cognitive behavioral therapy supported by virtual reality in the treatment of body image in eating disorders: One year follow-up. Psychiatry Research. 2013;209(3):619-625.

42. McLay R, Ram V, Murphy J, Spira J, Wood DP, Wiederhold MD, et al. Effect of virtual reality PTSD treatment on mood and neurocognitive outcomes. Cyberpsychology, Behavior, and Social Networking. 2014;17(7):439-346.

43. Opris D, Pintea S, Garcia-Palacios A, Botella C, Szamoskozi S, David D. Virtual reality exposure therapy in anxiety disorders: A quantitative meta-analysis. Depression and Anxiety. 2012;29(2):85-93.

44. Coyle H, Traynor V, Solowij N. Computerized and virtual reality cognitive training for individuals at high risk of cognitive decline: Systematic review of the literature. The American Journal of Geriatric Psychiatry. 2015;23(4):335-359.

45. Mrakic-Sposta S, Di Santo SG, Franchini F, Arlati S, Zangiacomi A, Greci L, et al. Effects of combined physical and cognitive virtual reality-based training on cognitive impairment and oxidative stress in MCI patients: A pilot study. Frontiers in Aging Neuroscience. 2018;10:282.

46. Wang M, Reid D. Using the virtual reality-cognitive rehabilitation approach to improve contextual processing in children with autism. The Scientific World Journal. 2013;2013.

47. Gongsook P. Time simulator in virtual reality for children with attention deficit hyperactivity disorder. Berlin:Spring- er;2012. pp. 490-493

48. Negut A, Jurma AM, David D. Virtual-reality-based attention assessment of ADHD: ClinicaVR: Classroom-CPT versus a traditional continuous performance test. Child Neuropsychology. 2017;23(6):692-712.

49. Serra-Pla JF, Pozuelo M, Richarte V, Corrales M, Ibanez $\mathrm{P}$, Bellina M, et al. Treatment of attention deficit hyperactivity disorder in adults using virtual reality through a mindfulness programme. Revista de Neurologia. 2017;64(S01):117-122. 50. Nolin P, Stipanicic A, Henry M, Lachapelle Y, Lussier-Desrochers D, Allain P. ClinicaVR: Classroom-CPT: A virtual reality tool for assessing attention and inhibition in children and adolescents. Computers in Human Behavior. 2016;59:327-333. 51. Cho BH, Ku J, Jang DP, Kim S, Lee YH, Kim IY, et al. The effect of virtual reality cognitive training for attention enhancement. CyberPsychology \& Behavior. 2002;5(2):129-137.

52. Gutierrez-Maldonado J, Letosa-Porta A, Rus-Calafell M, Penaloza-Salazar C. The assessment of attention deficit hyperactivity disorder in children using continous performance tasks in virtual environments. Anuario De Psicologia. 2009;40(2):211-222.

53. Parsons TD, Bowerly T, Buckwalter JG, Rizzo AA. A controlled clinical comparison of attention performance in children with ADHD in a virtual reality classroom compared to standard neuropsychological methods. Child Neuropsychology. 2007;13(4):363-381.

54. Rizzo AA, Buckwalter JG, Bowerly T, Van Der Zaag C, Humphrey L, Neumann U, et al. The virtual classroom: A virtual reality environment for the assessment and rehabilitation of attention deficits. CyberPsychology \& Behavior. 2000;3(3):483-499.

55. Pollak Y, Weiss PL, Rizzo AA, Weizer M, Shriki L, Shalev RS, et al. The utility of a continuous performance test embedded in virtual reality in measuring ADHD-related deficits. Journal of Developmental \& Behavioral Pediatrics. 2009;30(1):2-6.

56. Ehlis A. A biofeedback training in schoolchildren with an attention-deficit/hyperactivity disorder (ADHD). Tuebingen 
(Germany):University Hospital Tuebingen;2016.

57. Rostamian Z, Rasti J. The introduction of an interactive VR based platform for real videos. Fourth National Conference and 2nd International Computer Games Conference; Opportunities and Challenges. 201921 February 2; Isfahan, Iran. (Persian)

58. Rasti J, Manshaee GH, Eslami P. Design and validation of Virtual Reality Exposure Therapy Software for treatment of flying phobia. Knowledge \& Research in Applied Psychology. 2018;19(4):27-35. (Persian)

59. Tabrizi M, Manshaee G, Ghamarani A, Rasti J. Comparison of the effectiveness of virtual reality with medication on the memory of attention deficit hyperactivity disorder students. International Archives of Health Sciences. 2020;7(1):37-42.

60. Levesque J, Beauregard M, Mensour B. Effect of neurofeedback training on the neural substrates of selective attention in children with attention-deficit/hyperactivity disorder: A functional magnetic resonance imaging study. Neuroscience Letters. 2006;394(3):216-221.

61. Legerstee JS, Tulen JH, Dierckx B, Treffers PD, Verhulst FC, Utens EM. CBT for childhood anxiety disorders: Differential changes in selective attention between treatment responders and non-responders. Journal of Child Psychology and Psychiatry. 2010;51(2):162-172.

62. Brodeur DA, Pond M. The development of selective attention in children with attention deficit hyperactivity disorder. Journal of Abnormal Child Psychology. 2001;29(3):229-239.

63. Siriborvornratanakul T. A study of virtual reality headsets and physiological extension possibilities. In International Conference on Computational Science and Its Applications. 2016 July 4-7; Beijing, China. Springer, Cham. pp. 497-508.

64. Sadrosadat SJ, Hooshyari Z, Zamani R, Sadrosadat L. De- termination of psychometrics index of SNAP-IV rating scale in parent's execution. Archives of Rehabilitation. 2008;8(3):5965. (Persian)

65. Brodeur DA, Pond M. The development of selective attention in children with attention deficit hyperactivity disorder. Journal of Abnormal Child Psychology. 2001;29(3):229-239. 66. Faryabi MR, Javanmard M. The application of virtual reality. Advances in Engineering and Basic Science Conference. 2014 July 31; Ardabil, Iran;2014. (Persian)

67. Berry KJ, Mielke Jr PW. A generalization of Cohen's kappa agreement measure to interval measurement and multiple raters. Educational and Psychological Measurement. 1988;48(4):921-933.

68. Aman M, Kistler WD, Barrington Q, Sharp W, Persky S, Shaw P. Using virtual reality to define the mechanisms linking symptoms with cognitive deficits in attention deficit hyperactivity disorder. Scientific Reports. 2020;10(1):1-9.

69. Anton R, Opris D, Dobrean A, David D, Rizzo A. Virtual reality in rehabilitation of attention deficit/hyperactivity disorder The instrument construction principles. In 2009 Virtual Rehabilitation International Conference. 2009 Jun 29 - Jul 2; Haifa, Israel. IEEE. pp. 59-64.

70. Liao Y, Chen I, Lin YJ, Chen Y, Hsu W. Effects of virtual reality-based physical and cognitive training on executive function and dual-task gait performance in elderly individuals with mild cognitive impairment: A randomized control trial. Frontiers in Aging Neuroscience. 2019;11:162.

71. Bashiri A, Ghazisaeedi M, Shahmoradi L. The opportunities of virtual reality in the rehabilitation of children with attention deficit hyperactivity disorder: A literature review. Korean Journal of Pediatrics. 2017;60(11):337-343. 